University of South Carolina

Scholar Commons

7-2017

\title{
Assessing the Viability of Race-Neutral Alternatives in Law School Admissions
}

Eboni S. Nelson

University of South Carolina - Columbia, nelsones@law.sc.edu

Follow this and additional works at: https://scholarcommons.sc.edu/law_facpub

Part of the Law Commons

\section{Recommended Citation}

Eboni Nelson et. al., Assessing the Viability of Race-Neutral Alternatives in Law School Admissions, 102 IOWA L. REV. 2187 (2017).

This Article is brought to you by the Law School at Scholar Commons. It has been accepted for inclusion in Faculty Publications by an authorized administrator of Scholar Commons. For more information, please contact digres@mailbox.sc.edu. 


\title{
Assessing the Viability of Race-Neutral Alternatives in Law School Admissions
}

\author{
Eboni S. Nelson, ${ }^{*}$ Ronald Pitner, ${ }^{* *} \mathcal{E}$ Carla D. Pratt ${ }^{* * *}$
}

\begin{abstract}
Over the past several years, law schools have experienced many challenges stemming from declines in student enrollment due to a shrinking applicant pool. The declining number of applicants is particularly problematic for law schools seeking to educate students in racially diverse
\end{abstract}

* Professor of Law, University of South Carolina School of Law. J.D., Harvard Law School; B.A., Wake Forest University. My thanks to Danielle Holley-Walker, Meera Deo, Verna Williams, and Jeannine Bell for comments, suggestions, and discussion on this Article. Also, my thanks to workshop participants at the Lutie A. Lytle Black Female Faculty Writing Workshop for helpful discussion of some of the issues in this Article. I would also like to thank Chris Mathis, Carol Young and Vanessa Byars for their invaluable research and administrative assistance. This Article benefited greatly from the authors' attendance at the George Mason Law \& Economics Center LEC Workshop for Law Professors on Empirical Methods; therefore, we would like to thank workshop participants and instructors, specifically Jonathan Klick, Eric Hellend and Bruce Kobayashi. We also express our gratitude to the Access Group Center for Research \& Policy Analysis for providing grant funding to support this project. Finally, I thank Scott and Ella Nelson for their love, patience, and support. This Article is dedicated to my grandmother, Martha Ann Fowler, who always shared and rejoiced in my educational, professional, and personal achievements. May you find eternal rest in the loving arms of the Lord.

** I. DeQuincey Newman Endowed Chair and Director of the I. DeQuincey Newman Institute for Peace and Social Justice, Distinguished Associate Professor in Social Work Research; College of Social Work; University of South Carolina. I would like to thank Access Group for funding and supporting this research. I would also like to thank Elizabeth Thomas, Kyunghee Ma, and Trang Nguyen who were graduate assistants in charge of data entry. Finally, I want to thank the University of South Carolina's College of Social Work for being supportive of faculty who conduct transdisciplinary research designed to address social injustices. As an alumnus of the University of Michigan, I dedicate this article to all universities who actively work to increase the diversity of their student body population.

*** Associate Dean for Academic Affairs and Educational Equity, Nancy J. LaMont Faculty Scholar and Professor of Law; Pennsylvania State University, Dickinson Law. I too would like to thank Access Group for the funding that supported the research that is the foundation for this article and George Mason Law School for including us in their empirical methods workshop for law professors with special thanks to Jonathan Klick, Eric Helland and Bruce Kobayashi. Many thanks to my research assistants Olivia Phillips and Joslin Schultz for their able assistance in conducting some of the research to support this article. I would also like to thank the supportive community of Lutie A. Lytle scholars for their invitation to present this work when it was still in the preliminary phase, with special thanks to Angela Onwuachi-Willig. Last, but not least, I thank my now adult children Payton and Christopher Pratt for their enduring love and for their understanding when Mom's work intrudes on their time. Everything I do is for both of you. 
learning environments. In light of recent challenges to the constitutionality of race-conscious affirmative action and the likelihood that President Donald Trump will make several appointments to the Supreme Court-thereby shifting its balance toward the ideology of colorblindness-it is imperative to engage in a project that examines the relationship between racial categories and race-neutral identity factors in law-school admissions. Understanding the relationship between racial groups and certain race-neutral identity factors will help law schools comply with Fisher I's mandate that universities consider race-neutral means for achieving diversity before using race as a factor in their admissions processes. Understanding this relationship will also be useful for higher-education institutions seeking to enroll racially diverse student bodies in jurisdictions that do not permit the consideration of race in admissions, and may become necessary for all institutions if the Court overrules the Fisher and Grutter decisions. Moreover, the data from this study illuminates persisting structural inequalities for certain racial minority groups and rebuts the assumption that those privileged enough to make it to law school are insulated from the structural inequalities that race-conscious affirmative action historically sought to address.

This empirical study surveyed first-year law students at public American Bar Association approved law schools and asked them about race-neutral aspects of their identity, such as family background and educational-institution characteristics, to determine whether there is a relationship between their race and certain socioeconomic identity factors. The findings will enhance law schools' understanding of race-neutral admissions factors that may contribute to their abilities to assemble racially diverse student bodies, and will give them tools to experiment with trying to yield racially diverse classes without asking applicants about their race. Possessing such knowledge will greatly aid law schools as they develop and implement admissions policies in their efforts to provide greater access to students from backgrounds underrepresented in the legal profession while also fulfilling their commitment to educate all law students in a diverse learning environment.

I. INTRODUCTION 2189

II. THE DIVERSITY DILEMMA IN LAW SCHOOLS AND THE LEGAL

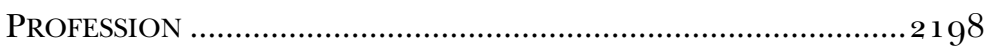

III. ACHIEVING DIVERSITY THEN AND NOW .....................................22202

A. THE BAKKE GUIDEPOST....................................................22202

B. THE DEMAND FOR MORE EXACTING SCRUTINY ......................22 206

IV. EXPERIMENTING WITH RACE NEUTRALITY ...............................2209

A. The TEXas Ten PERCENT Plan as a RaCE-Conscious MODEL OF RACE NEUTRALITY. 
B. USING RACE-NEUTRAL CRITERIA IN LAW-SCHOOL ADMISSIONS TO ACHIEVE RACIAL DIVERSITY.

1. Law Schools Have a Unique Opportunity to Experiment with Race Neutrality.... 2214

2. Study Design ... 2218

3. Data Collection 2222

4. Data Analysis 2223

V. FINDINGS 2225

VI. OBSERVATIONS .2232

VII. CONCLUSION 2233

\section{INTRODUCTION}

The past several years have been challenging for law schools because many have experienced declines in student enrollment due to a shrinking applicant pool. ${ }^{1}$ The declining number of applicants is particularly problematic for law schools in their attempts to enroll sufficient numbers of students to comprise incoming classes without sacrificing the numerical academic credentials of matriculating students. One such challenge concerns their efforts to educate students in racially diverse learning environments. ${ }^{2}$

For several decades, law schools have recognized and actively pursued the educational and social benefits commonly associated with assembling racially diverse student bodies. 3 In their efforts to enroll diverse classes, they have implemented strategies ranging from minority-targeted recruitment

1. See Ethan Bronner, Law Schools' Applications Fall as Costs Rise and Jobs Are Cut, N.Y. TIMES (Jan. 30, 2013), http://www.nytimes.com/2013/o1/31/education/law-schools-applications-fall-ascosts-rise-and-jobs-are-cut.html; Benjamin Wermund, Shrinking Applicant Pool Has Law Schools Competing to Cut Costs, Hous. CHRON. (June 1, 2014, 11 :o6 AM), http://www.houstonchronicle. $\mathrm{com} /$ news/education/article/Shrinking-applicant-pool-has-law-schools-5519781.php.

2. See generally Aaron N. Taylor, Diversity as a Law School Survival Strategy, 59 ST. LOUIS U. L.J. $321(2015)$.

3. See David Kow, The (Un)compelling Interest for Underrepresented Minority Students: Enhancing the Education of White Students Underexposed to Racial Diversity, 20 BERKELEY LA RAZA L.J. 157 , 159-61 (2010) (discussing the University of Michigan Law School's theory in Grutter v. Bollinger, 539 U.S. 306 (2003), that educational benefits from a diverse student body constituted a compelling interest that met strict scrutiny); Eli Wald, A Primer on Diversity, Discrimination, and Equality in the Legal Profession or Who is Responsible for Pursuing Diversity and Why, 24 GEO. J. LEGAL ETHICS 1079, 1118 (2011) (discussing law schools that have made a commitment to "formal diversity"); $c f$. Robert A. Sedler, Racial Preference in Law School Admissions: The Public Interest in a Diverse Legal Profession, 1 J.L. SOC'Y 17, 18 (1999) ("When racially preferential law school admissions policies were first adopted in the middle 1960 , the primary purpose for doing so was not to attain a racially diverse student body in law schools, although the programs had this clearly desirable educational effect."). 
programs 4 to minority-targeted financial aid.5 Considering applicants' races in admissions decisions has been pivotal to these efforts.

Since Justice Lewis F. Powell, Jr.'s pronouncement in Regents of the University of California $v$. Bakke approving the limited consideration of race in higher-education admissions decisions, ${ }^{6}$ race-conscious affirmative action has been an invaluable tool by which to provide countless minority students the opportunity to pursue legal education. As private and public universities have modeled their admissions programs on Justice Powell's discussion of permissible race-conscious policies, 7 affirmative action has played a critical role in diversifying law schools and the legal profession. ${ }^{8}$ Unfortunately, this role has diminished significantly due to ballot initiatives such as Proposition 209 in California 9 and Proposal 2 in Michigan, ${ }^{10}$ as well as legal challengesmost recently, Fisher $v$. University of Texas at Austin ("Fisher I").11

Despite the effectiveness of race-conscious admissions plans in helping to provide higher-education opportunities for students of color, ${ }^{12}$ opponents of race-conscious affirmative action continue to maintain that such policies

4. See Catherine E. Smith, Seven Principles: Increasing Access to Law School Among Students of Color, 96 IOWA L. REV. 1677, 1689-92 (2011) (discussing pipeline efforts at the University of Denver Sturm College of Law).

5. See generally Osamudia R. James, Dog Wags Tail: The Continuing Viability of Minority-Targeted Aid in Higher Education, 85 IND. L.J. $85_{1}^{1}$ (2010); John Nussbaumer \& Chris Johnson, The Door to Law School, 6 U. MASs. Roundtable SyMP. L.J. 1, 28-29 (2011); Stephen B. Thomas \& Judy L. Hirschman, Minority-Targeted Scholarships: More than a Black and White Issue, 2 1 J.C. \& U.L. 555 (1995).

6. Regents of the Univ. of Cal. v. Bakke, 438 U.S. 265,320 (1978) (recognizing that in the context of higher-education admissions, "the State has a substantial interest that legitimately may be served by a properly devised admissions program involving the competitive consideration of race and ethnic origin").

7. Grutter v. Bollinger, 539 U.S. 3o6, 323 (2003); see also Smith v. Univ. of Wash., Law Sch., 233 F.3d 1188, 1200 (9th Cir. 2000) ("If the various opinions in Bakke mixed so many different colors that the result became rather muddy, that result was still clear enough to permit educators to rely upon the opinion that gave the decision its life and meaning ... . More importantly, we are required so to do."); Cheryl I. Harris, Critical Race Studies: An Introduction, 49 UCLA L. REV. 1215 , 1223 n.17 (2002) (discussing how Justice Powell's opinion in Bakke shaped UCLA School of Law's admissions program and many others prior to Proposition 2o9).

8. See Jesse Rothstein \& Albert H. Yoon, Affirmative Action in Law School Admissions: What Do Racial Preferences Do?, 75 U. CHI. L. REV. 649, 697 (2008) (concluding "that affirmative action is responsible for nearly all of the diversity currently seen in the law student population generally and at every law school of even moderate selectivity").

9. CAL. CONST. art. I, $\S 31$.

10. Mich. CONST. art. I, $\$ 26$.

11. Fisher v. Univ. of Tex. at Austin (Fisher I), 133 S. Ct. 2411 (2013). On June 23, 2016 , the Supreme Court upheld the University of Texas' race-conscious admissions plan challenged in Fisher I. See Fisher v. Univ. of Tex. at Austin (Fisher II), 136 S. Ct. 2198,2214 (2016).

12. See Randall Kennedy, Persuasion and Distrust: A Comment on the Affirmative Action Debate, 99 HARV. L. REV. 1327, 1329 (1986) ("Affirmative action has strikingly benefited blacks as a group and the nation as a whole. . . Without affirmative action, continued access for black applicants to college and professional education would be drastically narrowed. To insist, for example, upon the total exclusion of racial factors in admission decisions, especially at elite institutions, would mean classes of college, professional and graduate students that are virtually devoid of Negro representation."); see also supra note 8 and accompanying text. 
violate the Equal Protection Clause of the Constitution. ${ }^{13}$ In 2003, the Supreme Court sanctioned the use of race-conscious admissions policies in higher education provided that universities adhere to constitutional standards of strict scrutiny as set forth by the Court. ${ }^{14}$ A decade later in Fisher $I$, the Court reiterated its prior holdings by holding that in order for an affirmative-action plan to pass constitutional scrutiny, the university implementing it must seek to achieve a compelling interest and its chosen means must be narrowly tailored to achieve it. ${ }^{15}$

The question of whether considering race is necessary for a university to achieve its diversity goals is of paramount importance to the Court's narrowly tailored inquiry. ${ }^{16}$ According to the Court, utilizing race-conscious admissions plans is impermissible if an institution of higher education "could achieve sufficient diversity without using racial classifications." ${ }^{17}$ The impact of raceneutral alternatives on the admissions process is central to this inquiry.

Fisher I clarified that the constitutionality of a race-conscious admissions plan depends upon the reviewing court's determination "that no workable race-neutral alternatives would produce the educational benefits of diversity." 18 While some opponents of affirmative action have been quick to assert that universities have several effective race-neutral alternatives at their disposal to avoid harms commonly associated with non-diverse learning

13. See Grutter v. Bollinger, 539 U.S. 306, 349 (2003) (Scalia, J., concurring in part and dissenting in part) ("The Constitution proscribes government discrimination on the basis of race, and state-provided education is no exception."); $i d$. at $35^{\circ}$ (Thomas, J., concurring in part and dissenting in part) ("I believe blacks can achieve in every avenue of American life without the meddling of university administrators. ... [and] I wish to see all students succeed whatever their color ...."). See generally Ward Connerly, It Is Time to End Race-Based "Affirmative Action”, 1 U. ST. ThOMAS J.L. \& PUB. POL'Y 56 (2007); Kermit Roosevelt III, The Ironies of Affirmative Action, 17 U. PA. J. CONST. L. $729(2015)$.

14. See Gratz v. Bollinger, 539 U.S. 244, 270 (2003) (holding that universities' raceconscious admissions policies must be "narrowly tailored to achieve the interest in educational diversity"); Grutter, 539 U.S. at 343 (sanctioning the "narrowly tailored use of race in admissions decisions to further a compelling interest in obtaining the educational benefits that flow from a diverse student body.").

15. Fisher I, 133 S. Ct. at 2419-20.

16. Id. at 2420 .

17. Fisher v. Univ. of Tex. at Austin (Fisher I), 133 S. Ct. 2411, 2420 (2013).

18. Id. 
environments, ${ }^{19}$ very little empirical evidence substantiates this claim. ${ }^{20}$ Rather, several studies have shown that eliminating race-conscious affirmative action would result in dramatic declines in the acceptance and enrollment rates for African-American ${ }^{21}$ and Hispanic applicants, especially at highly selective institutions. Researchers Thomas Espenshade and Chang Chung found that elite institutions that discontinued their use of affirmative action would affect undergraduate admissions significantly:

Acceptance rates for African-American candidates would fall from 33.7 percent to $\mathbf{1} 2.2$ percent, a decline of almost two-thirds, and the proportion of African-American students in the admitted class would drop from 9.0 to 3.3 percent. The acceptance rate for Hispanic applicants would be cut in half-from 26.8 percent to 12.9 percent, and Hispanics would comprise just 3.8 of all admitted students versus an actual proportion of 7.9 percent. ${ }^{22}$

19. See, e.g., Grutter, 539 U.S. at $361-62,367-71$, (Thomas, J., concurring in part and dissenting in part) (suggesting that universities try various race-neutral "admissions methods[] such as accepting all students who meet minimum qualifications," decreasing reliance on standardized test scores, and employing percent plans instead of relying on affirmative action to diversify their student body); Brief for the United States as Amicus Curiae Supporting Petitioner at 8-9, 13-2 1, Grutter v. Bollinger, 539 U.S. 306 (2003) (No. 02-241) 2003 WL 176635, at*8-9, *13-21 (arguing that the University of Michigan School of Law's race-conscious admissions policy was unconstitutional due to the availability of "ample race-neutral alternatives" by which to diversify its student body); Joshua P. Thompson \& Damien M. Schiff, Divisive Diversity at the University of Texas: An Opportunity for the Supreme Court to Overturn Its Flawed Decision in Grutter, 15 TEX. REV. L. \& POL. 437, 473 (2011) (asserting that the University of Texas' "race-neutral plan has been a demonstrable success"); L. Darnell Weeden, Employing Race-Neutral Affirmative Action to Create Educational Diversity While Attacking Socio-Economic Status Discrimination, 19 ST. JOHN's J. LEGAL COMMENT. 297, 334 (2005) (advocating for the Supreme Court's reconsideration of Grutter "[b] ecause the conceptual framework for effective race-neutral educational diversity demonstrated by the success of the Texas Top Ten Percent Plan could be designed to create true educational diversity based on socio-economic status"); Stephen Blea, Comment, The End of Affirmative Action: The Supreme Court's Opportunity to Overrule Grutter, 53 SANTA ClaRA L. REV. 1085, 1090-112 (2013) (discussing the Texas Top Ten Percent Plan as an effective race-neutral alternative to the University of Texas' race-conscious admissions plan in Fisher I).

20. One recent study suggests that a class-based affirmative-action plan may be able to maintain existing levels of racial diversity on a moderately selective public-university campus, if the institution structures it to account for both disadvantage and overachievement. Matthew $\mathrm{N}$. Gaertner \& Melissa Hart, Considering Class: College Access and Diversity, 7 HARv. L. \& POL'Y REV. 367 , 379 (2013) (showing a class-based affirmative-action policy at the University of Colorado yielded underrepresented minority students at rates comparable to those produced by race-conscious affirmative-action policies).

21. The authors recognize that the term "black" is more inclusive and encompasses all people of African descent regardless of their ethnicity. For purposes of this study and this Article, we collapsed all participants reporting African ancestry into a single racial group and refer to them by using the terms black and African-American interchangeably. Bi-racial and multi-racial participants in the study who reported some African ancestry were excluded from the Black/African-American category in an effort not to privilege one component of their identity over the other(s). We also use the terms Hispanic and Latina/o interchangeably herein.

22. Thomas J. Espenshade \& Chang Y. Chung, The Opportunity Cost of Admission Preferences at Elite Universities, 86 SOC. SCI. Q. 293, 298 (2005). 
Their results were consistent with other researchers' findings predicting steep declines in racial diversity if universities discontinue their use of raceconscious admissions policies. ${ }^{23}$

Researchers have also made similar predictions in the context of legal education. After examining 1990-1991 application and decision data for over 90,ooo applicants to 173 American Bar Association ("ABA") approved law schools, Professor Linda Wightman found that there would be "a substantial reduction in the overall number of applicants of color who were offered admission to ABA-approved law schools" if the schools abandoned raceconscious affirmative action. ${ }^{24}$ After replicating the study using 2000-2001 data, Wightman concluded that if law schools stopped considering race in admissions, minority student representation would experience substantial reductions. ${ }^{25}$

Indeed, there have been substantial declines in the number of students of color attending law schools-particularly those that are highly selectivewhich have discontinued race-conscious affirmative action, despite implementing race-neutral alternatives. ${ }^{26}$ Following the 1995 adoption of a Board of Regents resolution prohibiting University of California ("UC")

23. See, e.g., William G. Bowen \& Derek Bok, The Shape of the River: Long-Term CONSEQUENCES OF CONSIDERING RACE IN COLLEGE AND UNIVERSITY ADMISSIONS $15^{-5} 5^{2}$ (1998); Anthony P. Carnevale \& Stephen J. Rose, Socioeconomic Status, Race/Ethnicity, and Selective College Admissions, in AMERICA's UNTAPPED RESOURCE: LOW-INCOME STUdENTS IN HighER EdUCATION 101, 101-56 (Richard D. Kahlenberg ed., 2004); Thomas J. Kane, Racial and Ethnic Preferences in College Admissions, in THE BLACK-WHITE TEST ScORE GAP 431, 431-56 (Christopher Jencks \& Meredith Phillips eds., 1998); Victor B. Saenz et al., Losing Ground? Exploring Racial/Ethnic Enrollment Shifts in Freshman Access to Selective Institutions, in CHARTING THE FUTURE OF COLLEGE AfFirmative ACtion: Legal Victories, Continuing AtTACKS, AND New ReseARCH 79, 95 (Gary Orfield et al. eds., 2007); David L. Chambers et al., The Real Impact of Eliminating Affirmative Action in American Law Schools: An Empirical Critique of Richard Sander's Study, 57 STAN. L. REV. 1855,1857 (2005); Marvin Lim, Percent Plans: A "Workable, Race-Neutral Alternative" to Affirmative Action?, 39 J.C. \& U.L. 127, 142-48 (2013); Mark C. Long, College Applications and the Effect of Affirmative Action, $121 \mathrm{~J}$. ECONOMETRICS 319, 319-42 (2004); Rothstein \& Yoon, supra note 8, at 652.

24. Linda F. Wightman, The Threat to Diversity in Legal Education: An Empirical Analysis of the Consequences of Abandoning Race as a Factor in Law School Admission Decisions, 72 N.Y.U. L. REV. 1, 14 (1997).

25. Linda F. Wightman, The Consequences of Race-Blindness: Revisiting Prediction Models with Current Law School Data, 53 J. LEGAL EDUC. 229, $25^{1}$ (2003). Wightman's replication of the study using 2009-2010 data suggests similar conclusions regarding the detrimental impact of discontinuing the use of affirmative action in law-school admissions. LAW SCH. ADMISSIONS

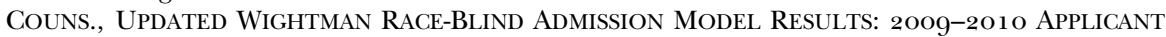
DATA 1-2 (Aug. 2012), http://www.lsac.org/docs/default-source/publications-(lsac-resources)/ raceblindadmissionresults.pdf.

26. Kevin R. Johnson \& Angela Onwuachi-Willig, Cry Me a River: The Limits of "A Systemic Analysis of Affirmative Action in American Law Schools," 7 AFR.-AM. L. \& POL'Y REP. 1, 9-10 (2005); Daria Roithmayr, Direct Measures: An Alternative Form of Affirmative Action, 7 MICH. J. RACE \& L. 1, 11 (2001); Carmina Ocampo, Prop 209: Ten Long Years, NATION (Nov. 22, 2006), https://www. thenation.com/article/prop-2og-ten-long-years; Julie J. Park, Black Men at UCLA: The Devastating Effects of Proposition 209, HufFINGTON POST: BLOG (Jan. 23, 2014) http://www.huffingtonpost.com/julie-jpark/black-men-at-ucla-the-dev_b_4297110.html; Erica Perez, Despite Diversity Efforts, UC Minority Enrollment Down Since Prop. 209, CAL. WATCH (Feb. 24, 2012), http://californiawatch.org/dailyreport/ despite-diversity-efforts-uc-minority-enrollment-down-prop-209-15031. 
schools from considering race in admission decisions and the 1996 passage of Proposition 209 banning affirmative action in California, the percentage of underrepresented minority students at UC Berkeley Law School ("Berkeley") declined from $25 \%$ in 1993 to $12 \%$ in $2005 .{ }^{27}$ UC Los Angeles School of Law ("UCLA") experienced similar declines as its percentage of underrepresented minority students decreased from $32 \%$ in 1994 to $11 \%$ in 2005, despite implementing race-neutral measures such as class-based affirmative action and new recruitment strategies. ${ }^{28}$ In 2014, neither Berkeley nor UCLA successfully enrolled the percentages of underrepresented minority students they had previously achieved in $1993 .{ }^{29}$

Similar declines in racial diversity occurred at the University of Michigan Law School ("Michigan") following the 2006 passage of Proposal 2, a state ballot initiative banning state universities from considering race in their admissions. In 2006, prior to Proposal 2, African-American students comprised $6.8 \%$ of Michigan's first-year class. $3^{\circ}$ In 20o8, the percentage decreased to $3.9 \% .3^{11}$ Although the percentage of African-American first-year students increased to $4.7 \%$ in 2014 , the overall percentage of African-American students at Michigan during the same year was only $3.6 \% .3^{2}$

Such declines in minority student enrollment evidence the difficulties that universities and law schools face as they endeavor to implement effective race-neutral alternatives so that students can realize the educational benefits of diversity. This study, which examines the relationship between the race of law students and their race-neutral identity factors, seeks to assist law schools in this endeavor. The findings of our study identify some race-neutral identity factors that align closely with race, such that a law school could experiment with them to determine whether it could achieve a racially-diverse class without asking applicants about their race.

27. Helen Hyun, Falling Sky: Trends in Minority Access to Law Schools, Pre-and Post-Gratz and Grutter, in Charting THE Future of College AfFirmative Action: Legal Victories, CONTINUING ATTACKS, AND NEW RESEARCH 105, $114^{-15}$ (Gary Orfield et al. eds., 2007).

28. $I d$.

29. In 2014, Berkeley's student body was comprised of $12.3 \%$ Hispanic students, $4.4 \%$ African-American students, and $.4 \%$ American Indian students. UnIV. OF CAL., BERKELEY, UNIVERSITY OF CALIFORNIA, BERKELEY - 2014 STANDARD 5 O9 INFORMATION REPORT 1 (2014), https://www.law.berkeley.edu/files/Std5ogInfoReport_2014.pdf. During the same year, UCLA's enrollment was comprised of only 9.6\% Hispanic students, 3.5\% African-American students, and $.9 \%$ American Indian students. UNIV. OF CAL., L.A., UNIVERSITY OF CALIFORNIA, LOS ANGELES - 2014 STANDARD 5 O9 INFORMATION REPORT 1 (2014), https://web.archive.org/web/20150905181002/ http://www.law.ucla.edu/ /media/Assets/Admissions/Documents/Std5ogInfoReport-9-1 0-1 202-2014\% 2013-1 1-58.ashx.

3o. Greg Stohr, Black Enrollment Falls as Michigan Rejects Affirmative Action, BLOOMBERG (Sept. 23, 2013, 9:01 PM), https://www.bloomberg.com/news/articles/2013-og-24/black-enrollmentfalls-as-michigan-rejects-affirmative-action.

31. Id.

32. UNIV. OF MICH., UNIVERSITY OF MICHIGAN - 2014 STANDARD 5 Og INFORMATION REPORT 1 (2014), http://www.law.umich.edu/aboutus/Documents/Std 5 ogInfoReport-76-76-1 2-1 2-2014\% $2015^{-3} 3^{1-5}$.pdf. 
Building on prior research examining racial diversity in legal education,33 this study surveyed first-year law students attending a crosssection of public34 ABA approved law school.35 The participants were asked about various aspects of their backgrounds related to educational experiences and family circumstances. The study compared students' responses to their self-identified racial categories to determine the relationship between students' race and race-neutral identity factors.

The findings presented herein suggest that considering certain raceneutral factors may equip law schools with a means to test whether they could use race-neutral admissions to assemble racially diverse classes. $3^{6}$ Because African-American and Hispanic students are significantly more likely than

33. See generally Walter R. Allen \& Daniel Solórzano, Affirmative Action, Educational Equity and Campus Racial Climate: A Case Study of the University of Michigan Law School, 12 BERKELEY LA RAZA L.J. 237 (2001); Meera E. Deo et al., Paint by Number? How the Race and Gender of Law School Faculty Affect the First-Year Curriculum, 29 Chicana/O-Latina/O L. ReV. 1 (2010); Meera E. Deo, The Promise of Grutter: Diverse Interactions at the University of Michigan Law School, 17 MICH. J. RACE \& L. 63 (2011); Meera E. Deo et al., Struggles Eீ Support: Diversity in U.S. Law Schools, 23 NAT'L BLACK L.J. 71 (2010); Rachel F. Moran, Diversity and its Discontents: The End of Affirmative Action at Boalt Hall, 88 CAL. L. REV. 2241 (200o); Rothstein \& Yoon, supra note 8; Richard H. Sander, A Systemic Analysis of Affirmative Action in American Law Schools, 57 STAN. L. REV. 367 (2004); see also generally Charles E. DAYE ET Al., LAW Sch. Admission Council, The Educational Diversity Project: ANALYSIS OF LONGITUDINAL AND CONCURRENT STUDENT AND FACULTY DATA (2010), http://www. lsac.org/docs/default-source/research-(lsac-resources)/gr-10-01.pdf.

34. For the purposes of this study, a "public" law school is a law school that is situated within a broader university structure that legislative action created, and receives an annual funding appropriation from a government.

35. The study focuses on ABA approved law schools because the ABA Council on Legal Education, the accrediting body for law schools, imposes a diversity standard that all law schools must satisfy. Consequently, ABA approved law schools have a need to be concerned with diversity in the student body in order to be in compliance with ABA regulations. ABA Standard 206, which governs diversity and inclusion, provides:

(a) Consistent with sound legal education policy and the Standards, a law school shall demonstrate by concrete action a commitment to diversity and inclusion by providing full opportunities for the study of law and entry into the profession by members of underrepresented groups, particularly racial and ethnic minorities, and a commitment to having a student body that is diverse with respect to gender, race, and ethnicity.

(b) Consistent with sound educational policy and the Standards, a law school shall demonstrate by concrete action a commitment to diversity and inclusion by having a faculty and staff that are diverse with respect to gender, race, and ethnicity.

AM. BAR ASs'N, ABA STANDARDS AND RUles OF Procedure FOR APPROVAL OF LAW SCHOOLS 2015-2016, at 12 (2015), http://www.americanbar.org/content/dam/aba/publications/misc/ legal_education/Standards/2015_2016_aba_standards_for_approval_of_law_schools_final. authcheckdam.pdf.

36. See infra Parts V and VI. Not all law schools are similarly situated. Some draw students from local regions while others have a very diverse applicant pool. Moreover, applicant pools change from year to year. Consequently, the tools provided by the findings of this study might work to aid some law schools in achieving a racially diverse student body while at the same time fail to achieve racial diversity at other law schools. Likewise, the tool could work at a law school for while then cease to be effective if there are significant changes in the applicant pool. For this reason, it is important for law schools to test the viability of the methodology in the study rather than assuming that it will yield a critical mass of students from groups underrepresented in law school. 
white students to endorse race-neutral factors such as qualifying for free or reduced lunch during elementary and secondary school, receiving a Pell Grant during college, and having a parent or guardian who received public assistance while he or she was growing up,37 law schools' consideration of these and similar factors in their admissions decisions may be a useful way for law schools to test, in a single admission cycle, whether using race-neutral means is sufficient to achieve their diversity goals. A law school could ask questions on its application regarding these race-neutral identity factors and weight them in the admissions process..$^{8}$ In so doing, the law school would effectively expand the definition of merit beyond academic credentials to include applicants who have demonstrated determination to overcome structural challenges. Redefining merit in this way could help ensure that the enrolling class would be diverse, because not all applicants would have demonstrated merit merely through their Law School Admission Test ("LSAT") score and undergraduate grade point average ("UGPA"). Moreover, an admissions standard that seeks to admit students who have overcome structural inequality strikes at the heart of what proponents originally intended race-conscious affirmative action to do.

This Article reports on research that provides law schools with tools by which to experiment with race-neutral admissions. The research was confined to 10 law schools. Consequently, it does not claim that all law schools, or any law school, will be able to assemble a racially diverse class using race-neutral admissions. Instead, it argues that law schools now have some data to use for experimenting with a race-neutral admissions cycle as a means of complying with Fisher I's mandate that schools seriously consider race-neutral alternatives before resorting to the use of race. 39

It is important to note that although the study found statistically significant relationships between race and certain race-neutral identity factors, this Article does not advocate for the wholesale substitution of traditional race-conscious admissions measures with them. Rather, it encourages law schools to utilize such race-neutral factors in their admissions processes as a means of complying with Fisher I and testing the viability of raceneutral measures. Also, because there were some schools in our sample that

37. See infra Part IV.

38. Admittedly, these types of questions are very personal in nature, and some applicants might not wish to answer them. Consequently, we recommend that law schools make the questions optional and explain why they are being asked. For example, the application could state: We define merit by looking beyond LSAT scores and UGPAs to ascertain whether candidates for admission have overachieved relative to the advantages or disadvantages they have experienced. If you want the admissions committee to consider your achievements pursuant to this more thorough assessment, please answer the following questions.

39. Experimentation might take the form of a race-neutral admissions cycle, but for those law schools that do not wish to risk experiencing a loss of diversity, the experimentation could be done by conducting a parallel phantom race-neutral admission cycle with all or a random portion of the applicant pool to compare the outcome of a race-neutral approach with the outcome of a race-conscious approach. If the race-conscious approach produced significantly more racial diversity than the race-neutral approach, the law school would know that it should not attempt a race-neutral admission because considering race was necessary to achieve a racially diverse class. 
had very low levels of racial diversity, a race-neutral admission cycle might increase the percentages of students from underrepresented racial groups by eliminating implicit bias that may be operating in some admissions processes effectively to stop admissions of applicants from underrepresented groups once there appears to be a critical mass of non-white students. On the other hand, schools with such little diversity that there is no critical mass of any underrepresented racial group may find that their diversity suffers even more when they eliminate racial considerations from their admissions decisions. Consequently, each law school must conduct its own mini-study to determine whether using race-neutral admissions would sustain or improve diversity there. It is our hope that this study provides some tools for law schools to use to engage in such experimentation.

Experimenting with a race-neutral admission cycle could expand educational opportunities for students of color at some law schools while also addressing opponents' and proponents' concerns that current affirmativeaction policies violate the Constitution $4^{\circ}$ and/or disproportionately benefit privileged minority students from middle- and high-class backgrounds. $4^{1}$ Based on the sample of participants in our study, it is clear that privilege did not catapult many law students of color to law school. Many of them had to overcome the structural inequalities of public education, poverty, and race to make it to law school. Expanding opportunities for these and other minority students will benefit not only legal education and the legal profession, but also society more broadly.

Part II briefly examines the current state of racial diversity in ABA approved law schools. It discusses the historical underrepresentation of certain minority groups in law school, which has led to a profound lack of racial diversity in the legal profession. Part III discusses the constitutional landscape governing the use of race-conscious affirmative action in higher education. In light of the Supreme Court's recent holdings in Fisher I, this Part explains why empirically examining the availability and viability of raceneutral measures to achieve student-body diversity is an important and necessary endeavor.

Part IV examines the Texas Ten Percent Plan as a race-conscious model of race neutrality and describes the study's design and methodology. Part V presents our study's descriptive and inferential findings. Based on these findings, Part VI offers observations and suggestions to aid law schools as they develop and implement admissions policies to provide greater access to students from backgrounds that are underrepresented in the legal profession.

40. See supra note 13 and accompanying text.

41. See, e.g., Stephen L. Carter, Reflections of An AfFirmative ACtion Baby 8o ( 1991 ); Charles J. OGLETREe, JR., All Deliberate SPEed: Reflections on the First Half Century of BROWN V. BOARD OF EDUCATION 250-51, 260-62 (2004); Tomiko Brown-Nagin, Elites, Social Movements, and the Law: The Case of Affirmative Action, 105 COLuM. L. REV. 1436, 1476-77 (2005); Sheryll Cashin, Place, Not Race: Affirmative Action and the Geography of Educational Opportunity, $47 \mathrm{U}$. MiCH. J.L. REFORM 935, 940-41 (2014); Mark Nadel, Retargeting Affirmative Action: A Program to Serve Those Most Harmed by Past Racism and Avoid Intractable Problems Triggered by Per Se Racial Preferences, 8o ST. JOHN's L. REV. 323, 325 
Engaging in this endeavor will help law schools fulfill their commitment and obligation to educate all law students in a diverse learning environment.

\section{The Diversity DilemMA IN LAW SCHOOLS AND THE LEGAL ProfESSION}

Like other post-baccalaureate degree-granting institutions, $4^{2}$ law schools have experienced an overall increase in racial diversity over the past several decades. From 1971 to 2014 , the total enrollment of minority students in ABA approved law schools increased from $6.1 \%$ to $26.9 \% .43$ Similarly, the percentage of Juris Doctor ("JD") degrees awarded to minority students increased from $8.6 \%$ to $25.5 \%$ between 1983 and 2013.44 While these statistics are significant achievements, a closer examination of diversity in law schools and the legal profession reveals disconcerting realities that counter the beneficial promise of these figures.

Consider, for instance, the percentage of historically underrepresented minority students, such as African-Americans and Hispanics, 45 who attend the

42. From 1976 to 2013 , the percentage of racial/ethnic minority U.S. residents enrolled in degree-granting post-baccalaureate institutions increased from $10.4 \%$ to $33.5 \%$. Table 3o6.Io: Total Fall Enrollment in Degree-Granting Postsecondary Institutions, by Level of Enrollment, Sex, Attendance Status, and Race/ethnicity of Student: Selected Years, 1976 through 2013, NAT'L CTR. FOR EDUC. STATISTICS, https://nces.ed.gov/programs/digest/d14/tables/dt14_3o6.10.asp (last visited Apr. 20, 2017).

43. AM. BAR Ass'N, ABA APPROVED 1ST YeAR JD AND MinORITy ENROLlMENT: FALL 2013, http://www.americanbar.org/content/dam/aba/administrative/legal_education_and_admissions_ to_the_bar/statistics/2013_jd_enrollment_1yr_total_minority_.xls (last visited Apr. 20, 2017); AM. BAR ASS'N, LAWYER DEMOGRAPHICS YEAR 2016, http://www.americanbar.org/content/dam/aba/ administrative/market_research/lawyer-demographics-tables-2016.pdf (last visited Mar. 13, 2017).

44. AM. BAR ASS'N, ABA APPROVED TOTAL JD AND MiNORITY DEGREES AWARDED: FALL 2013, http://www.americanbar.org/content/dam/aba/administrative/legal_education_and_admissions_ to_the_bar/statistics/2013_jd_degrees_minority.xls (last visited Apr. 20, 2017).

45. Although discussing racial diversity broadly encompasses members of all racial and ethnic minority groups, university administrators, jurists, scholars, and policymakers often refer "to the inclusion of students from groups which have been historically discriminated against, like African-Americans, Hispanics and Native Americans," when discussing policies affecting underrepresented minority students. Grutter v. Bollinger, 539 U.S. 3o6, 316 (2003) (internal citations omitted). As noted by Judge Henry Ramsey, Jr.:

Blacks, Hispanics, and Native Americans experience poorer health and substantially lower levels of health care, fewer high school and college graduates, a greater percentage of high school drop outs, an Internet gap, higher rates of unemployment, higher arrest rates, higher criminal convictions and incarceration rates, higher rates of teen-age pregnancy, higher levels of family poverty, lower home ownership rates, and lower levels of savings and investment in securities than white Americans ... . I have no doubt that these are continuing consequences of centuries of American racism, and, particularly, the horrific discrimination that occurred in the United States during the first six decades of the Twentieth Century.

Henry Ramsey, Jr., Response to Dean Herma H. Kay's Affirmative Action Paper, 34 IND. L. REV. 87, 89 (2000). For thought-provoking discussions regarding the beneficiaries of affirmative action, particularly within the black community, see generally Kevin Brown \& Jeannine Bell, Demise of the Talented Tenth: Affirmative Action and the Increasing Underrepresentation of Ascendant Blacks at Selective Higher Educational Institutions, 69 OHIO ST. L.J. 1229,1230 (2008) (discussing how "blacks whose predominate ancestry is traceable to the historical oppression of blacks in the United States are likely more underrepresented in affirmative action than most administrators, admissions 
country's highest-ranked law schools, as determined by U.S. News E World Report. In 2014, the African-American enrollment at each of the top fifteen law schools did not reach $9 \% .4^{6}$ Harvard Law School's ("Harvard's") enrollment was the highest at $8.7 \%$, while Michigan's African-American enrollment was the lowest at 3.6\%.47 For the $2015^{-2016}$ academic year, the African-American enrollment at Harvard and Michigan increased to $9 \%^{4}$ and $4 \%, 49$ respectively. At Yale Law School ("Yale"), which is consistently ranked as the top law school in the country, $5^{\circ}$ African-American enrollment decreased from $6.9 \%$ in 2014 to $6.2 \%$ in $2015^{5^{1}}$

Sadly, the Hispanic enrollment at these and other highly selective law schools is similarly low. During the 2015-2016 academic year, Hispanic students accounted for $8.3 \%$ of Yale's student body $5^{2}$ and $9.2 \%$ of Harvard's. 53 The Hispanic enrollment at Michigan during the same academic year was only 3.7\%.54 Therefore, although the total minority enrollment at these and other top-ranked schools may be as high as $32.9 \%$ largely due to Asian student enrollment, as was the case at Yale during the $2015^{-2016}$ academic year, 55 the enrollment of traditionally underrepresented minority students continues to be disproportionately low at law schools throughout the country. This unfortunate reality detrimentally impacts not only the law schools but also the legal profession more broadly.

In recent years, minority law students across the country have fervently voiced their concerns regarding issues related to the lack of diversity and inclusion on their campuses. The scope of their concerns has included the lack of student, faculty, and staff diversity; law schools' failure to adequately include the perspectives of communities of color in the presentation and

committees, or faculties may realize"); and Angela Onwuachi-Willig, The Admission of Legacy Blacks, 6o VAND. L. REV. 1138 (2007) (analyzing the generational admission statistics of black students).

46. Ranking the Top Law Schools by Their Percentage of Black Students, J. BLACKS IN HiGHER EDUC. (Dec. 3O, 2014), http://www.jbhe.com/2014/12/ranking-the-top-law-schools-by-their-percentage-ofblack-students [hereinafter Ranking the Top Law Schools].

47. See id. (showing Top Law School Rankings).

48. HARVARD LAW SCH., HARVARD LAW SCHOOL - 2015 STANDARD 5 O9 INFORMATION REPORT 1 (2015), http://hls.harvard.edu/content/uploads/2015/12/2015-ABA-Standard-509-Report.pdf.

49. UNIV. OF MiCH., UNIVERSITY OF MICHIGAN - 2015 STANDARD 5 O9 INFORMATION REPORT 1 (2015), http://www.law.umich.edu/aboutus/Documents/Std5ogInfoReport-76-76-1 2-17-2015_ 12-57-o8.pdf.

50. See Derek Tam, Briefly: Law School Tops U.S. News Rankings-Again, Yale DaILY NEWS (Apr. 24, 2009), http://yaledailynews.com/blog/2009/o4/24/briefly-law-school-tops-u-s-newsrankings-again (reporting that U.S. News $\mathcal{E}$ World Report has ranked Yale No. 1 every year since it began ranking law schools in 1983).

51. See Ranking the Top Law Schools, supra note 46; YALE UnIV., YALE UNIVERSITY - 2014 STANDARD 5 O9 INFORMATION REPORT 1 (2014), http://www.abarequireddisclosures.org; YALE UNIV., YALE UNIVERSITY - 2015 STANDARD 509 INFORMATION REPORT 1 (2015), http://www. abarequireddisclosures.org.

52. See Yale UnIV., supra note $5^{1}$, at 1 .

53. HARVARD LAW SCH., supra note 48 , at 1 .

54. UNIV. OF MICH., supra note 49 , at 1.

55. See YAle UnIV., supra note $5{ }^{1}$, at 1. 
discussion of course material; and schools' utilization of offensive institutional symbols. $5^{6}$ Many students of color, particularly African-American law students, have felt isolated and pressured to be "spokespersons for their race" due, in part, to the lack of diversity on their campuses. 57 Considering that these are precisely the feelings that schools intend diverse learning environments to combat, $5^{8}$ recent student accounts demonstrate the failure of some law schools to enroll a sufficient number of minority students to achieve this goal successfully.

While the lack of meaningful racial diversity in any educational setting is troubling, it is especially problematic when it occurs at highly selective elite colleges and law schools. As the Supreme Court recognized in Grutter v. Bollinger, the most selective higher-education institutions play a critical role in educating those citizens who are likely to become the nation's future leaders.59 This is particularly true "when it comes to highly selective law schools" because they can serve as gateways to the country's most prominent governmental and legal professional positions. ${ }^{60}$

As Justice Sandra Day O'Connor noted in Grutter, “[a] handful of these schools accounts for 25 of the 1 oo United States Senators, 74 United States Courts of Appeals judges, and nearly 200 of the more than 6oo United States District Court judges." ${ }^{61}$ In addition, the vast majority of tenured and tenuretrack professors in the legal academy typically graduate from a small subset of

56. See Jordan Raymond, Why I'm Sleeping in Belinda Hall, HARV. CrimSON (Mar. 4, 2016), http://www.thecrimson.com/article/2016/3/4/raymond-belinda-hall-protest (detailing students' concerns at Harvard Law School); Terrell Jermaine Starr, Black Washington And Lee Law Students Say They Were 'Bamboozled' About School's Diversity, NEwSONE, https://newsone.com/3005288/blackwashington-and-lee-law-students-say-they-were-bamboozled-about-schools-diversity (last visited Apr. 20, 2017) (reporting students' concerns at Washington and Lee University School of Law); Samantha Tomilowitz \& Sam Hoff, UCLA Law Students Protest Lack of Diversity, DAILY BRUIN (Feb. 10, 2014, 4:10 PM), http:/ / dailybruin.com/2014/02/10/ucla-law-students-protest-lack-of-diversity (discussing students' concerns at UCLA School of Law).

57. Grutter v. Bollinger, 539 U.S. 3o6, 318-19 (2003); see also Tomilowitz \& Hoff, supra note $5^{6 .}$

58. See Fisher v. Univ. of Tex. at Austin (Fisher I), 133 S. Ct. 2411, 2418 (2013) ("The attainment of a diverse student body ... serves values beyond race alone, including enhanced classroom dialogue and the lessening of racial isolation and stereotypes."); Grutter, 539 U.S. at 318-19 (discussing a university official's testimony concerning practices meant to ensure "that underrepresented minority students do not feel isolated or like spokespersons for their race"); Vinay Harpalani, The Double-Consciousness of Race-Consciousness and the Bermuda Triangle of University Admissions, 17 U. PA. J. CONST. L. 821, 832 n.41 (2015) (discussing university efforts to create a "critical mass").

59. See Grutter, 539 U.S. at 331 (discussing the importance of diversity in the "country's ... most selective [educational] institutions"” to facilitate "a highly qualified, racially diverse [military] officer corps" (quoting Consolidated Brief of Lt. Gen. Julius W. Becton, Jr. et al. as Amici Curiae in Support of Respondents at 29, Grutter v. Bollinger, 539 U.S. 306 (2003) (Nos. 02-241, 02-516), 2003 WL 1787554, at $\left.*_{29}\right)$ ); id. at 332 ("Moreover, universities, and in particular, law schools, represent the training ground for a large number of our Nation's leaders.").

6o. Id. at 332 .

61. Id. 
highly ranked law schools, ${ }^{62}$ most notably Harvard and Yale. ${ }^{63}$ Considering that "underrepresented minority graduates of elite U.S. law schools . . . have strongly disproportionate leadership contributions (relative to other law schools) in the ranks of corporate law firm partners, the professoriate and the federal judiciary," 64 the lack of racial diversity in these schools and law schools more broadly has led to a lack of diversity in many facets of the legal profession. ${ }^{65}$

Recently, Professor Deborah Rhode has described law as "one of the least racially diverse professions in the nation." 66 Despite the nearly $29 \%$ of minority students enrolled in law school during the 2013-2014 academic year, ${ }^{67}$ lawyers of color account for only $12 \%$ of the profession in $2010 .{ }^{68}$ The percentages are even lower at the higher echelons of the legal profession, where only $9 \%$ of general counsels at large corporations and $7 \%$ of law-firm partners are minority attorneys. ${ }^{69}$ People of color are also underrepresented in legal academia, where roughly $85 \%$ of male tenured professors and $77 \%$ of female tenured professors are white. $7^{\circ}$

62. See Kevin R. Johnson, The Importance of Student and Faculty Diversity in Law Schools: One Dean's Perspective, 96 IOWA L. REV. 1549, 1559 (2011) (identifying a degree from an elite law school as a desired credential for law schools seeking to hire new professors); Richard E. Redding, "Where Did You Go to Law School?" Gatekeeping for the Professoriate and Its Implications for Legal Education, 53 J. LEGAL EDUC. 594, 594-95 (2003) (discussing the historical and accelerating trend of law faculties hiring graduates "from a handful of elite law schools"); L. Darnell Weeden, Back to the Future: Should Grutter's Diversity Rationale Apply to Faculty Hiring? Is Title VII Implicated?, 26 BERKELEY J. EMP. \& LAB. L. $5^{11}$, 534 (2005) (discussing elite law schools' desire to hire faculty members with similar elite academic credentials).

63. See Justin McCrary et al., The Ph.D. Rises in American Law Schools, I96o-20 I I: What Does It Mean for Legal Education?, 65 J. LEGAL EDUC. 543, 554 (2016); Redding, supra note 62, at 6o6-07.

64. William C. Kidder, Misshaping the River: Proposition 209 and Lessons for the Fisher Case, 39 J.C. \& U.L. 53, 119 (2013); see also Chambers et al., supra note 23, at 1866 (noting that "the earnings of graduates of lower-tier schools are in general much lower than the earnings of the graduates of elite schools"); Johnson, supra note 62, at 1559 ("Many law schools aggressively recruit minority faculty candidates, with the competition especially keen for those with the most elite credentials.").

65. See Johnson \& Onwuachi-Willig, supra note 26, at 8 ("Severe underrepresentation of minorities can be found in legal education, the bar, and judiciary."); Weeden, supra note 62, at 539 (observing that law schools' requirement of elite academic credentials for faculty hires will produce "social barriers that unnecessarily promote racial and ethnic stratification").

66. Deborah L. Rhode, Law is the Least Diverse Profession in the Nation. And Lawyers Aren't Doing Enough to Change That., WASH. POST: POSTEvERYTHING (May 27, 2015), https://www.washingtonpost. $\mathrm{com} /$ posteverything/wp/2015/05/27/law-is-the-least-diverse-profession-in-the-nation-and-lawyersarent-doing-enough-to-change-that/?utm_term=.d480280076fo. But see generallyJason P. Nance \& Paul E. Madsen, An Empirical Analysis of Diversity in the Legal Profession, 47 CONN. L. REV. 271 (2014) (finding that although racial minorities continue to be underrepresented in the legal profession, the profession is on par with other professions when it comes to diversity).

67. See AM. BAR ASS'N, LAWYER DEMOGRAPHICS YEAR 2016, supra note 43 .

68. See id.; Rhode, supra note 66 (explaining that $88 \%$ of lawyers are White).

69. Rhode, supra note 66.

7O. AM. BAR ASS'N, DATA FROM THE 2013 ANNUAL QUESTIONNAIRE: ABA APPROVED LAW SCHOOL STAFF AND FACULTY MEMBERS, GENDER AND ETHNICITY: FALL 2013 (2013), http://www.americanbar. org/content/dah/aba/administrative/legal_education_and_admissions_to_the_bar/statitstics/2013 _law_school_staff_gender_ethnicity.xlsx; see also Meera E. Deo, Looking Forward to Diversity in Legal 
Although legal scholars and practitioners often cite to a "pool problem" to explain the lack of racial diversity among their ranks ${ }^{71}$ - a claim that is highly debatable ${ }^{2}$-increasing racial diversity in law schools would be an important first step in helping eliminate the stark racial disparities that currently plague the legal profession. Historically, affirmative action has served as an invaluable tool by which to diversify law schools.73 However, as the next Part details, the Supreme Court's decision in Fisher v. University of Texas at Austin cautions law schools' continual reliance on the use of race in admissions without sufficient justification for employing such measures. 74

\section{ACHIEVING DIVERSITY THEN AND Now}

\section{A. THE BAKKE GUIDEPOST}

For several decades, institutions of higher education-including law schools-have recognized the social and educational benefits that commentators commonly associate with diverse learning environments. 75 Such benefits range from promoting greater understanding between students of different races $7^{6}$ to legitimizing our democracy and its leaders. 77 In their efforts to achieve these and other diversity-begotten benefits, colleges and universities have employed a wide variety of measures to assemble racially diverse student bodies. $7^{8}$ Realizing that " $[\mathrm{t}]$ he tools for constructing the pool of potential applicants are indissolubly linked to the goal of constructing a

Academia, 29 BERKELEYJ. GENDER, L. \& JUST. 352, 357 (2014) (stating that, in 2014, at least $72 \%$ of law faculty members were white); Weeden, supra note 62 , at $5^{1} 3^{-14}$ (citing statistics showing low minority representation on law school faculties).

71. See Rhode, supra note 66 (reporting that surveyed attorneys "attributed the underrepresentation of minorities to the lack of candidates in the pool").

72. See Deo, supra note 70 , at $359-64$ (rejecting the claim that the lack of minority female law professors is due to a non-diverse pool of applicants); Rhode, supra note 66 (challenging the "pool problem" contention and attributing minority lawyers' high rates of attrition in law firms to several factors such as unconscious bias and lack of mentoring, networking and clientdevelopment opportunities).

73. See supra notes 8, 12 and accompanying text; see also infra Part III.

74. See generally Fisher v. Univ. of Texas at Austin (Fisher I), 133 S. Ct. 2411 (2013).

75. See, e.g., Devon W. Carbado, Intraracial Diversity, 6o UCLA L. REV. 1130, 1144-46 (2013); Osamudia R. James, White Like Me: The Negative Impact of the Diversity Rationale on White Identity Formation, 89 N.Y.U. L. REV. 425, 446-49 (2014); Eboni S. Nelson, Examining the Costs of Diversity, 63 U. Miami L. REV. 577, $5^{86-92}$ (2009).

76. See Grutter v. Bollinger, 539 U.S. 3o6, 330 (2003); see also Tomiko Brown-Nagin, The Diversity Paradox: Judicial Review in an Age of Demographic and Educational Change, $6_{5}$ VAND. L. REV. EN BANC 1 13, 129-32 (2O12) (discussing university administrators' challenges in ensuring that cross-racial understanding actually takes place on diverse campuses).

77. See Grutter, 539 U.S. at 332; see also Stacy Hawkins, Diversity, Democracy E Pluralism: Confronting the Reality of Our Inequality, 66 MERCER L. REV. 577, 607-08 (2015) (discussing the aspirational goal of democratic legitimacy as embedded within the diversity rationale).

78. See generally OFFICE FOR CIVIL Rights, U.S. DEP'T OF EDUC., RACE-NEUTRAL ALTERNATIVES IN POSTSECONDARY EDUCATION: INNOVATIVE APPROACHES TO DIVERSITY (2003), https://www.gpo.gov/ fdsys/pkg/ERIC-ED 475547/pdf/ERIC-ED 475547.pdf (discussing a variety of race-neutral developmental and admissions programs utilized by colleges and universities in their attempts to diversify their student bodies). 
diverse learning environment,"79 institutions have attempted to increase the number of minority applicants to their schools by establishing regional admissions offices in minority-populated cities and dispatching recruiters to predominantly minority high schools and colleges. ${ }^{80}$ They have also offered minority-targeted financial aid in the forms of race-conscious and raceexclusive awards to encourage students of color to attend their schools. ${ }^{81}$

Although these and similar programs have been and continue to be integral in diversifying higher education, ${ }^{82}$ institutional employment of raceconscious affirmative action has been one of the most effective measures for assembling a diverse student body. ${ }^{83}$ By considering an applicant's race as one of many factors when making admissions decisions, universities directly capture those students whose life experiences have been shaped, in part, by their identity as a racial minority. The unique experiences and perspectives that these students bring into the academic environment are vital to universities achieving the educational benefits of diversity. Therefore, proponents of affirmative action rely upon this diversity rationale to justify the use of race-conscious admissions policies in higher education. ${ }^{8}$

Supreme Court Justice Lewis Powell first articulated the diversity rationale nearly 40 years ago in Regents of the University of California v. Bakke. ${ }^{85}$ Although the Court invalidated the University of California at Davis Medical School's ("Medical School's") separate admissions program for minority

79. Gerald Torres, Grutter v. Bollinger/Gratz v. Bollinger: View From a Limestone Ledge, 103 COLUM. L. REV. 1596,1599 (2003).

8o. See Catherine L. Horn \& Stella M. Flores, Civil Rts. Project at Harvard Univ. Percent Plans in COllege Admissions: A COMPARATIVE ANALYSIS OF THREE STATES' EXPERIENCES 55 (2003), http:/ / civilrightsproject.ucla.edu/research/college-access/admissions/percent-plans-in-collegeadmissions-a-comparative-analysis-of-three-states2019-experiences/horn-percent-plans-2003.pdf.

81. See James, supra note 5 , at 854 (distinguishing between race-conscious aid that considers race "as one of many factors . . . in selecting award recipients" and race-exclusive aid that "limit[s] aid eligibility to applicants from a minority racial or ethnic group"). Colleges and universities have also employed race-neutral financial aid programs, such as the Longhorn Scholars Program implemented at the University of Texas following the Fifth Circuit's ban on affirmative action in Hopwood v. Texas, to assemble a racially diverse student body. Torres, supra note 79, at 1604. As Professor Gerald Torres noted, "[b]ecause most students of color in Texas tend to come from poor high schools, poor school districts, and poor families with less-educated providers, the scholarship program has successfully increased the number of African American and Mexican American applicants." Id.

82. See Torres, supra note 79, at 1599 ("Activities like outreach, recruitment, and financial aid are critical to" maximizing diversity at colleges and universities.).

83. See Douglas Laycock, The Broader Case for Affirmative Action: Desegregation, Academic Excellence, and Future Leadership, 78 TUL. L. REV. 1767 , 1768 (2004) ("Affirmative action has been the most effective method, and generally the only effective method, of desegregating schools with highly selective admission standards ...."); Ramsey, supra note 45 , at 89 ("Affirmative action has been demonstrated to be one of the most effective means for overcoming barriers to higher education that are presented by the continuing consequences of racial discrimination.").

84. See James, supra note 75, at 431-32 ("The diversity rationale-the defense of affirmative action policies based on a compelling interest in diversity-thus justifies the use of race-conscious policies in pursuit of this worthy goal.").

85. See generally Regents of the Univ. of Cal. v. Bakke, 438 U.S. 265 (1978). 
applicants, ${ }^{86}$ Justice Powell wrote separately to endorse its goal of attaining a diverse student body, ${ }^{8} 7$ which he clearly found to be "a constitutionally permissible goal for an institution of higher education." 88 According to Justice Powell, a university exercises its academic freedom, which is grounded in the First Amendment, when it seeks to assemble a student body comprised of diverse people with diverse perspectives who can contribute to the vigorous exchange of ideas that take place on college campuses. ${ }^{89}$ This freedom, however, is not limitless, and higher-education institutions must exercise it in a constitutionally permissible manner, $9^{\circ}$ which the Medical School failed to do by implementing a separate admissions procedure that included a prescribed number of seats in each class only for ethnic minority students. $9^{1}$

In critiquing the Medical School's program, Justice Powell outlined the features of a university's admissions plan that lawfully considers race in its efforts to achieve the compelling interest of student-body diversity within the contours of strict scrutiny. $9^{2}$ Such features include considering race or ethnicity as one of a "broader array of qualifications and characteristics,"93 individualized consideration of all applicants in comparison with each other,94 and no "fixed number of places to a minority group."95 Although some argue that Justice Powell expressed his own views and not necessarily those of the Court, $9^{6}$ university administrators seized upon his discussion and modeled their own race-conscious admissions programs on his opinion.97 Bakke's role as a guidepost for universities seeking to diversify their student bodies continued for 25 years, until the Court officially sanctioned affirmative

86. Id. at 320 .

87. Id. at $311-15$.

88. Id. at 311-12.

89. Id. at $3^{12-13}$.

9o. Id. at 314 ("Although a university must have wide discretion in making the sensitive judgments as to who should be admitted, constitutional limitations protecting individual rights may not be disregarded.").

91. See id. at $3{ }^{1} 5$; see also id. at 320 ("The fatal flaw in petitioner's preferential program is its disregard of individual rights as guaranteed by the Fourteenth Amendment.").

92. Id. at $3^{1} 5^{-1} 9$.

93. Id. at 315 .

94. Id. at $3^{17}$ ("In such an admissions program, race or ethnic background may be deemed a 'plus' in a particular applicant's file, yet it does not insulate the individual from comparison with all other candidates for the available seats." (footnote omitted)).

95. Id. at 316 .

96. Jurists have debated whether Justice Powell's discussion of the diversity rationale is binding precedent because no other Justice joined that part of the opinion. See Grutter v. Bollinger, 539 U.S. 306,325 (2003) (discussing divergent cases considering this issue); Joelle A. Marty, Comment, Affirmative Action in Higher Education: Federal Circuit Court Split Over Bakke's Diversity Rationale, $3_{6}$ U.C. DAVIS L. REV. 505, $5^{\mathrm{o} 8 \mathrm{nn} .9-10}$ (2003) (comparing the approaches of different circuit courts in interpreting the Supreme Court's decision in Bakke).

97. See supra note 7 and accompanying text; see also Jim Chen, Embryonic Thoughts on Racial Identity as New Property, 68 U. COLO. L. REV. 11 23, 1127 (1997); Jim Chen, Diversity and Damnation, 43 UCLA L. REV. 1839, 1859 (1996). 
action in higher education in its companion cases of Gratz $v$. Bollinger ${ }^{8}$ and Grutter v. Bollinger99-both of which Bakke's guiding principles heavily influenced. ${ }^{100}$

In both cases, which challenged the race-conscious undergraduate and law school admissions policies the University of Michigan employed, ${ }^{101}$ the Court recognized the pursuit of "the educational benefits that flow from a diverse student body" ${ }^{102}$ as a compelling interest to justify considering an applicant's race in admissions decisions. ${ }^{103}$ In so doing, the Court invoked Justice Powell's reasoning in Bakke by acknowledging universities' educational autonomy and granting them deference in their judgment that student-body diversity is critical to their academic mission. ${ }^{104}$

Bakke also served as a guide for the Court as it articulated and examined the contours of a permissible narrowly tailored race-conscious admissions program. In upholding the plan in Grutter, the Court found that Michigan's consideration of race as a permissible "plus factor" afforded each applicant the sort of individualized consideration Justice Powell had contemplated. ${ }^{105}$ In contrast, the undergraduate admissions program that Gratz challenged-which automatically awarded 20 points to all minority applicants-impermissibly allowed race essentially to serve as the determinative criteria for admissions decisions. ${ }^{106}$ In so doing, the Court found that the plan conflicted with the principles that Bakke set forth and prevented applicants from receiving the individualized consideration due them under the Equal Protection Clause of the Fourteenth Amendment. ${ }^{107}$

Following Grutter, university administrators had at their disposal a new "touchstone for constitutional analysis of race-conscious admissions policies" ${ }^{108}$ and a model for the type of race-conscious plan that would pass constitutional scrutiny. ${ }^{109}$ Some institutions, such as the University of Texas, began to reinstitute affirmative-action programs they had previously

98. See generally Gratz v. Bollinger, 539 U.S. 244 (2003).

99. See generally Grutter, 539 U.S. 306.

10o. See Gratz, 539 U.S. at 270-75; Grutter, 539 U.S. at 322-25, 333-43.

101. See Gratz, 539 U.S. at 257 (challenging the University of Michigan's consideration of race in undergraduate admissions); Grutter, 539 U.S. at 316-17 (challenging the University of Michigan Law School's consideration of race in admissions decisions).

102. Grutter, 539 U.S. at 343 .

103. Id. at 325 ("endors[ing] Justice Powell's view that student body diversity is a compelling state interest that can justify the use of race in university admissions"); Gratz, 539 U.S. at 268 (2003) (rejecting petitioners' argument that diversity in admissions is not a compelling interest).

104. Grutter, 539 U.S. at $328-29$.

105. Id. at $334-41$.

106. Gratz, 539 U.S. at $270-75$.

107. See id.

108. Grutter, 539 U.S. at 323 (referring to Justice Powell's opinion in Bakke).

109. See Michael A. Fletcher, Decision Means Most Colleges Will Stay Course, WASH. Post, June 24, 2003, at Aog (describing Grutter and Gratz as "a road map for crafting affirmative action programs that pass constitutional muster"). 
abandoned, ${ }^{110}$ which set the stage for yet another Supreme Court inquiry into their constitutionality. However, unlike the Court's decision in Grutter that unquestionably endorsed the diversity-rationale tenets that Bakke set forth, the Court's recent decision in Fisher I challenged and restricted Grutter's guidelines for employing race-conscious admissions plans to achieve the benefits of diversity. ${ }^{11}$

\section{B. THE DEMAND FOR MORE EXACTING SCRUTINY}

In Fisher I, plaintiff Abigail Fisher filed suit against the University of Texas at Austin ("UT"), the state's "flagship" ${ }_{12}$ public university, ${ }^{113}$ alleging that its consideration of race in admissions decisions violated the Fourteenth Amendment's Equal Protection Clause. ${ }^{114}$ Both the federal district court and the Fifth Circuit upheld UT's policies and practices in conducting race-

110. See Defendants' Reply Memorandum in Support of Cross-Motion for Summary Judgment at 2-5, Fisher v. Univ. of Tex. at Austin, 645 F. Supp. $2 d 5^{87}$ (W.D. Tex. 2oog) (No. 1 :o8-CV-o0263-SS), 2009 WL 5055457; Press Release, The Univ. of Tex. at Austin, The University of Texas at Austin Reacts to the Supreme Court's Affirmative Action Decisions (June 23, 2003), https://news.utexas.edu/2003/o6/23/nr_affirmativeaction. Some institutions, such as Texas A\&M University and the University of Georgia, decided not to reinstitute their affirmative action policies; see also Nancy G. McDuff \& Halley Potter, Ensuring Diversity Under Race-Neutral Admissions at the University of Georgia, in THE Future of AFFIRMATIVE Action: New PATHS TO HigheR EDUCATION DIVERSITY AFTER FISHER V. UNIVERSITY OF TEXAS 1 22, 124 (Richard D. Kahlenberg ed., 2014); Marc Levin, Texas A ENM Slaps Down Reverse Discrimination, FRONTPAGEMAG.COM (Dec. 11 , 2003), http:/ / archive.frontpagemag.com/readArticle.aspx?ARTID $=15044$.

111. See John C. Brittain, Affirmative Action Survives Again in the Supreme Court on a Legal Technicality: An Analysis of Fisher v. University of Texas at Austin, 57 How. L.J. 963, 973-74 (2014) (noting that the majority in Fisher I considered parts of its strict scrutiny analysis to be "at odds with Grutter"); John A. Powell \& Stephen Menendian, Fisher v. Texas: The Limits of Exhaustion and the Future of Race-Conscious University Admissions, 47 U. MICH. J.L. REFORM 899, 904 (2014) (discussing "the ways in which the Fisher decision departs from precedent, proscribes new limits on the use of race in university admissions, and tightens requirements for narrow tailoring”); Fourteenth Amendment-Equal Protection Clause-Public-University Affirmative Action-Fisher v. University of Texas at Austin, 127 HARV. L. REV. 258, 263 (2013) [hereinafter Fourteenth Amendment] ("Thus, the means-ends distinction Justice Kennedy articulated in Fisher as consistent with Grutter was birthed as a critique of the Grutter majority. Whichever Justice has the better of the constitutional argument, there is a doctrinal shift here . . ..”).

1 12. States generally use the term "flagship" to refer to their most selective public institutions of higher education from a student-admissions perspective. The term here acknowledges that usage, but the authors make no claim beyond that.

113. See, e.g., Brief for the United States as Amicus Curiae Supporting Respondents at 2, Fisher v. Univ. of Tex. at Austin (Fisher I), 133 S. Ct. 2411 (2013) (No. 11-345), 2012 WL 3418588 , at $*_{2}$ ("The University of Texas at Austin (the University) is the flagship institution of Texas's public university system.”); Brief Amici Curiae of 53 Current Members of the Texas State Senate \& House of Representatives in Support of Respondents at 1, Fisher I, 133 S. Ct. 2411 (No. 11-345), 2015 WL 669oo38, at $*_{1}$ (stating the same). Many people also often consider Texas A\&M University to be one of Texas's flagship institutions. See Brief of the American Educational Research Ass'n et al. as Amici Curiae in Support of Respondents at 32-36, Fisher I, 133 S. Ct. 2411 (No. 11-345), 2012 WL 3527825 , at $*_{24}$ (identifying UT and Texas A\&M as Texas's flagship institutions); Brief Amicus Curiae of the Black Women Lawyers Ass'n of Greater Chicago, Inc., in Support of Respondents at 24, Grutter v. Bollinger, 539 U.S. 306 (2003) (No. 02-241) \& Gratz v. Bollinger, 539 U.S 244 (2003) (No. 02-516) (stating the same).

114 . Fisher I, 133 S. Ct. at 2417. 
conscious admissions. ${ }^{115}$ Both lower courts held that racial diversity was a compelling state interest and that UT had narrowly tailored its admissions policies that took account of race to fit the compelling governmental interest of racial diversity. ${ }^{116}$

Writing for the Court in Fisher I, Justice Anthony Kennedy began by affirming the holding in Bakke that achieving the educational benefits that flow from diverse learning environments is a compelling state interest. ${ }^{1{ }^{17}}$ In doing so, however, Justice Kennedy refined and constrained the diversity rationale by clarifying that it is the educational benefits that flow from racial diversity that are the compelling governmental interest, and not racial diversity alone. ${ }^{118}$ The opinion characterizes racial diversity independent of educational benefits as "racial balancing," which the Court clearly denounces as unconstitutional in this context. ${ }^{119}$

In discussing the compelling interest it identified in Bakke and sanctioned in Grutter, the Fisher I Court failed to recognize important states' interests that public universities further by educating students from diverse backgrounds. ${ }^{120}$ Unlike Justice O'Connor, who broadly discussed the social, democratic, and educational benefits of diversity in Grutter, ${ }^{121}$ Justice Kennedy referred only to those diversity values realized in academic settings, such as "enhanced classroom dialogue and the lessening of racial isolation and stereotypes" among students. ${ }^{122}$ " $[\mathrm{S}]$ tate $[\mathrm{s}$ '] interest[s] in debunking racial stereotypes" within their citizenry and "creating a racially diverse workforce for the labor market" are also embedded in the diversity rationale and, therefore, constitute broad compelling goals that go far beyond the narrow scope of diversity benefits Fisher I recognized. ${ }^{123}$

Interestingly, Justice Kennedy made a point of noting that justices "disagree[d] about whether Grutter was consistent with the principles of equal protection in approving this compelling interest in diversity." ${ }^{24}$ By

\footnotetext{
115. Id.

116. See, e.g., Fisher v. Univ. of Tex. at Austin, 631 F.3d 213, 230-31, 247 (5th Cir. 2011), vacated and remanded by Fisher I, 133 S. Ct. 2411 (2013); Fisher v. Univ. of Tex. at Austin, 645 F. Supp. $2 d$ 587, 604, 612 (W.D. Tex. 2009), vacated and remanded by Fisher I, 133 S. Ct. 2411 (2013). 117. Fisher $I, 133$ S. Ct. at 2417-18.

118. See Carla D. Pratt, The End of Indeterminacy in Affirmative Action, 48 VAL. U. L. REV. 535, $55^{1}$ (2014) ("By constraining the diversity interest to only the interest in using diversity to achieve educational benefits, the Court has created an unnecessary disjuncture between public and educational interests in diversity in higher education.").

119. Fisher v. Univ. of Tex. at Austin (Fisher I), 133 S. Ct. 2411, 2419 (2013) (quoting Grutter v. Bollinger, 539 U.S. 3 o6, 330 (2003)).

120. See Pratt, supra note 118 , at $55^{\mathrm{O}-52}$ ("[T] he state's interest in making public-funded higher education equally accessible to all races or achieving racial equality in educational outcomes arguably would not be . . a compelling governmental interest . ...”).

121. See Grutter, 539 U.S. at 329-33 (describing the various benefits that diversity provides to higher education, specifically law schools).

122. Fisher I, 133 S. Ct. at 2418.

123. Pratt, supra note 118 , at 549-51 (citing Grutter, 539 U.S. at $33^{\circ}$ ).

124. Fisher I, 133 S. Ct. at 2419 .
} 
acknowledging only the educational benefits resulting from student-body diversity, the Court constrained its previous articulation of the permissible constitutional interest at stake and, thereby, made the first prong of the strictscrutiny test more narrow and stringent for public universities seeking to assert the compelling governmental interest of diversity. ${ }^{125}$

Fisher I also calls for stricter scrutiny than the Court relied on in Grutter for courts determining whether a race-conscious plan is narrowly tailored. In discussing a university's pursuit of diversity's educational benefits, Justice Kennedy agreed with Justice O'Connor that academic freedom provides colleges and universities with some latitude to determine their educational missions and goals. ${ }^{126}$ Therefore, "some, but not complete, judicial deference is proper" 127 when courts decide the constitutionality of educational institutions' compelling interests.

However, in an apparent departure from Grutter, ${ }^{128}$ Fisher I made clear that courts should afford no such deference when they review universities' chosen means by which to achieve their educational goals. ${ }^{129}$ According to the Court, "the $[\mathrm{u}]$ niversity receives no deference" ${ }^{13^{\circ}}$ and must convince the reviewing court that its use of "race to achieve the educational benefits of diversity" is a "necessary" endeavor. ${ }^{131}$

The Court's discussion of this newly articulated necessity standard heightens the scrutiny under which courts will adjudicate race-conscious admissions plans $^{13^{2}}$ and, thereby, amplifies the importance of universities'

\footnotetext{
125. See supra notes 100-07 and accompanying text.
}

126. See Fisher v. Univ. of Tex. at Austin (Fisher I), 133 S. Ct. 2411 , 2419 (2013); see also Vinay Harpalani, Narrowly Tailored but Broadly Compelling: Defending Race-Conscious Admissions After Fisher, 45 Seton Hall L. Rev. 761, 814-16 (2015) (discussing universities' abilities to define their educational goals in light of the deference that Fisher I granted to them).

127. Fisher I, 133 S. Ct. at 2419 .

128. See, e.g., Grutter v. Bollinger, 539 U.S. 306, 343 (2003) ("We take the Law School at its word that it would 'like nothing better than to find a race-neutral admissions formula' and will terminate its race-conscious admissions program as soon as practicable."); id. at 364 (Thomas, J., dissenting) ("The majority's broad deference to both the Law School's judgment that racial aesthetics leads to educational benefits and its stubborn refusal to alter the status quo in admissions methods finds no basis in the Constitution or decisions of this Court."); id. at 388 (Kennedy, J., dissenting) ("The Court confuses deference to a university's definition of its educational objective with deference to the implementation of this goal."); Fisher v. Univ. of Tex. at Austin, 631 F.3d 213, 232 (5 th Cir. 2011) (concluding that Grutter held that "the narrowtailoring inquiry-like the compelling-interest inquiry-is undertaken with a degree of deference to the University's constitutionally protected, presumably expert academic judgment"); Eboni S. Nelson, In Defense of Deference: The Case for Respecting Educational Autonomy and Expert Judgments in Fisher v. Texas, 47 U. RicH. L. REV. 1133 , 1136 n.15 (2013) (detailing jurists' and scholars' findings that Grutter afforded deference to the Law School's judgments regarding both its educational goals and the means by which to achieve them).

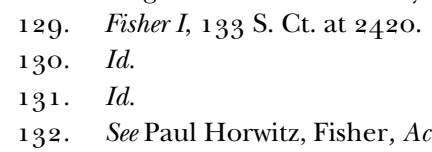
(noting that affirmative action "programs would face more rigorous review" under Fisher $I$ ); Eboni S. Nelson, Reading Between the Blurred Lines of Fisher v. University of Texas, 48 VAL. U. L. REV. $5^{19}$, 528-30 (2014) (discussing Justice Kennedy's articulation of the narrowly tailoring requirement 
consideration of race-neutral alternatives as Grutter requires. ${ }^{133}$ In raising the constitutional bar for using race in higher-education admissions decisions, Fisher I mandates that, regarding race-neutral alternatives:

Consideration by the university is of course necessary, but it is not sufficient to satisfy strict scrutiny: The reviewing court must ultimately be satisfied that no workable race-neutral alternatives would produce the educational benefits of diversity. If "a nonracial approach ... could promote the substantial interest about as well and at tolerable administrative expense," then the university may not consider race. ${ }^{134}$

Consequently, universities seeking to produce racially diverse student bodies that yield educational benefits and achieve their educational goals must first consider ${ }^{135}$ race-neutral means for achieving such benefits and goals prior to resorting to using race. In light of this, examining the viability of race-neutral alternatives in higher-education admissions is both an important and necessary endeavor.

\section{EXPERIMENTING WITH RACE NEUTRALITY}

\section{A. The TeXas Ten Percent Plan as a Race-Conscious Model of Race NEUTRALITY}

Texas has been a battleground state in the debate over race-conscious affirmative action. In the mid-1990s, a non-profit organization called the

in Fisher 1); Powell \& Menendian, supra note 111, at 908-15 (discussing the ways in which the Fisher I Court created more stringent narrowly tailoring requirements for race-conscious admissions plans); Richard Sander \& Aaron Danielson, Thinking Hard About "Race-Neutral" Admissions, 47 U. MICH. J.L. REFORM 967, 967 (2014) (suggesting that Fisher Is subtle differences in language "seem[] significantly tougher and harder to evade than the language of earlier Court decisions"); Robert Smith, Affirmative Action Survives Fisher (Sort of), but What About Schuette, 1 SUFFOLK U. L. REV. ONLINE 65, 71-72 (2013) (noting that Justice Kennedy's opinion in Fisher I “'tighten[s] up' the level of scrutiny in Grutter"); Fourteenth Amendment, supra note 11 1, at 267 (concluding that Fisher I recalibrated Grutter's strict scrutiny analysis of race-conscious admissions plans).

133. See Grutter, 539 U.S. at 339-40 (finding plans that are "narrowly tailored" should "require serious, good faith consideration of workable race-neutral alternatives that will achieve the diversity the university seeks").

134. Fisher I, 133 S. Ct. at 2420 (internal citations omitted) (emphasis added).

135. Although "consider" arguably means "try" race-neutral alternatives that could plausibly yield racial diversity, there does not appear to exist a consensus regarding the meaning of Grutter's mandate to consider race-neutral alternatives. See, e.g., George La Noue \& Kenneth L. Marcus, "Serious Consideration" of Race-Neutral Alternatives in Higher Education, 57 CATH. U. L. REV. 991, 1001 (2008) (finding the Grutter decision held that "universities must rigorously evaluate appropriate race-neutral policies to determine the extent to which they support the institution's specific diversity goals"); Calvin Massey, The New Formalism: Requiem for Tiered Scrutiny?, 6 U. PA. J. CONST. L. 945, 978-79 (2004) (discussing the consequences of the Grutter decision and the implications of the Court's narrow tailoring standard); Powell \& Menendian, supra note 111, at 9o8-o9 (discussing the race-neutral alternative standard set forth in Grutter and how the Fisher Court has seemingly made the standard more "stringent"); Michael E. Rosman, The Quixotic Search for RaceNeutral Alternatives, 47 U. MICH. J.L. REFORM 885, 893-94 (2014) (discussing the Grutter Court's problems with "percentage plans" and its rejection of other "race-neutral" plans). 
Center for Individual Rights ${ }^{13^{6}}$ began to implement a strategy to challenge the consideration of race in higher-education admissions. They identified four law-school applicants to whom the University of Texas School of Law ("UTSL") had denied admission and who were willing to serve as plaintiffs in litigation aimed at challenging its race-conscious affirmative-action policies and practices. The petitioners named Cheryl Hopwood, a white single mother, as the lead plaintiff, and she and the other three plaintiffs sued the UTSL in federal court alleging that its admissions practice of considering the race of applicants in making admission decisions violated the Fourteenth Amendment of the U.S. Constitution. ${ }^{137}$ After losing her claim in the trial court, Hopwood appealed to the Fifth Circuit. In 1996, a five-judge panel revisited the diversity rationale the U.S. Supreme Court endorsed in Bakke and held that diversity in education does not serve a compelling state interest. ${ }^{138}$ However, in holding the UTSL's race-conscious admissions procedures unconstitutional, the court gratuitously suggested that a system that preferred the underprivileged without regard to race would be constitutional even if it had the effect of disproportionately aiding minorities. ${ }^{139}$

Using the superfluous language of Hopwood as guidance, the Texas legislature responded to the Fifth Circuit's decision by adopting the Top Ten Percent Plan ("Plan"). ${ }^{14}$ The Plan was race-conscious in that the legislators who adopted it were aware that its design would leverage existing de facto segregation in public schools and yield racial diversity in the students admitted to the University of Texas and all public universities in the state. ${ }^{14^{1}}$ Nonetheless, the Fifth Circuit in Hopwood opened the door and the majority in Fisher I implied the Plan was race-neutral because, by its terms, it did not distinguish between applicants on the basis of race, and it specifically precluded public universities in Texas from doing so. ${ }^{14^{2}}$ By leveraging the

136. CTR. FOR INDIVIDUAL RTS., https://www.cir-usa.org (last visited Apr. 20, 2017 ).

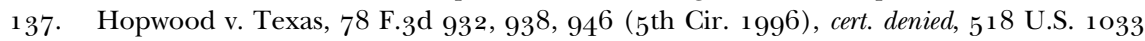
(1996), abrogated by Grutter v. Bollinger, 539 U.S. 306 (2003). The law school operated an admissions program in which it evaluated each applicant based on his or her "Texas Index number," a mathematical composite of UGPA and LSAT score. Id. at 935. Based on this score, it deemed an applicant either a "presumptive admit," "presumptive deny," or "discretionary" candidate for admission. Id. The ranges of scores established for placing minority applicants in each of these categories were lower than the ranges of scores fixed for non-minorities, such that the school could assign a white applicant and a black applicant with the same composite score to different categories. Id. at 936-37. For example, it could assign a white applicant with a composite score of $\mathrm{X}$ to the presumptive deny category, while it could assign a black applicant with that same composite score to the presumptive admit category. $I d$.

138. Id. at 934; see also Carla D. Pratt, In the Wake of Hopwood: An Update on Affirmative Action in the Education Arena, 42 How. L.J. 451, 457-58 (1999).

139. Hopwood, $78 \mathrm{~F} .3 \mathrm{~d}$ at 946.

140. TeX. EDUC. CoDE ANN. $\$ 51.803$ (West 2016). See also Brian T. Fitzpatrick, Strict Scrutiny of Facially Race-Neutral State Action and the Texas Ten Percent Plan, 53 BAYLOR L. REV. 289, 290 (2001); Leslie Yalof Garfield, The Paradox of Race-Conscious Labels, 79 BROOK. L. REV. 1523, 1529-31 (2014).

141. See Fisher v. Univ. of Tex. at Austin (Fisher I), 133 S. Ct. 2411, 2433 (2013) (Ginsberg, J., dissenting) (citing HOUSE RESEARCH ORG., BILL ANALYSIS, HB $5884-5$ (1997), http://www.lrl.state.tx. us/scanned/hroBillAnalyses $/ 75^{-\mathrm{O} / \mathrm{HB}_{5}} 88 . \mathrm{PDF}$ ).

142. Id. at $24^{1} 5^{-16}$. 
neighborhood segregation of Texas cities and the resulting de facto ${ }^{143}$ segregation in Texas public schools that the neighborhood segregation generated, the Plan extended admission to elite Texas public universities to many students who otherwise would have been unable to compete for admission because they had received an inferior education in the K-12 segment of the public education pipeline. ${ }^{144}$

From 1997 to 2004, the Plan operated as the primary means by which public institutions of higher education in Texas could diversify their student bodies. ${ }^{145}$ Universities continued to read applications of prospective students to determine whether applicants had unique talents or attributes to contribute to the diversity of the school, such as athletic ability, musical or artistic talent, or a unique geographical background, but they did not consider race in their admissions processes during this period. ${ }^{1} 4^{6}$ However, the Supreme Court decided Grutter in 2003, which overruled the decision in Hopwood that had deemed unconstitutional all race-conscious affirmative action in higher-education institutions located in the Fifth Circuit. ${ }^{147}$ Consequently, in 2004, the University of Texas began using a hybrid admissions system that admitted the bulk of students in accordance with the Plan, but admitted the remainder of students through a holistic review of individual applicants that considered various identity factors including race. ${ }^{14}$ The Fisher $I$ plaintiffs subsequently challenged this two-prong approach by arguing that the race-conscious prong of the UT's admissions

143. Unlike de jure segregation, which laws impose, de facto racial segregation occurs in public schools because of racially segregated housing patterns that emerged during the Jim Crow era and persist today. Consequently, Texas is not alone in having de facto segregation as a contemporary vestige of de jure segregation. See Maurice C. Daniels \& Cameron Van Patterson, (Re)considering Race in the Desegregation of Higher Education, 46 GA. L. REV. 521,544 n.119 (2012) (" $[\mathrm{R}]$ acial segregation in schools is a function of residential segregation, which is inextricably linked to socioeconomic inequalities that are related to the legacy of Jim Crow laws, policies, and practices.”); Lino A. Graglia, Solving the Parents Involved Paradox, 31 SEATTLE U. L. REV. 911 , 913 n.15 (2008) (explaining the distinction between de jure and de facto race segregation). See also generally SHerYll CASHIN, Place, NOT RACE: A NEW Vision OF OPPORTUNITY IN AMERICA (2014) (offering a way forward that seeks to address the inferior education caused by racially segregated housing patterns, and arguing that using place instead of race in diversity programming will better amend the structural disadvantages endured by many children of color, while enhancing the possibility that society move past the racial resentment that affirmative action engenders).

144. See Preston Green, Affirmative Action: A Tool for Rebuilding the K-I 2 Segment of the Pipeline, in THE END OF THE PIPELINE: A JOURNEY OF RECOGNITION FOR AFRICAN AMERICANS ENTERING THE LegAl Profession 139, 139-5o (Dorothy H. Evensen \& Carla D. Pratt eds., 201 2) (pointing out that the reason we continue to need race-conscious affirmative action is because states have not fulfilled the promise of Brown and relegate so many children of color to racially segregated, underfunded, inferior schools for their primary and secondary educations).

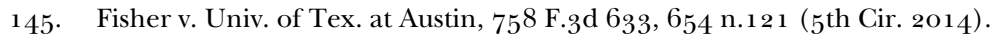

146. Garfield, supra note 140 , at 1531 .

147. See Grutter v. Bollinger, 539 U.S. 3o6, 343 (2003) (abrogating Hopwood by allowing the limited use of race considerations for admissions decisions). The Court also decided Gratz $v$. Bollinger, 539 U.S. 244, 251, 255-57 (2003), which struck down an affirmative action policy and procedure applied to undergraduate admissions because it assigned points to individuals from certain racial groups rather than conducting an individualized holistic review of each applicant.

148. Fisher, $75^{8 \mathrm{~F}} \cdot 3^{\mathrm{d}}$ at $637-38$. 
policy was not necessary to achieve student-body diversity because the "raceneutral" Plan achieved the goal of racial diversity without resorting to considering any applicant's race. ${ }^{149}$

A Supreme Court majority in Fisher I viewed the Plan as race neutral because it operated without the UT considering the race of applicants who graduated in the top $10 \%$ of their high-school classes. In her dissent, Justice Ruth Bader Ginsburg essentially called the majority's characterization of the Plan as race-neutral a legal fiction. She asserted that the Plan was raceconscious because the Texas Legislature had adopted it knowing that it would operate to admit a racially diverse group of Texas high school graduates to the UT and other public colleges in Texas. ${ }^{15^{\circ}}$ In the Gratz case involving undergraduate admissions at the University of Michigan, Justice Ginsberg stated in her dissent that "'percentage plans' are just as race conscious as the point scheme [used by Michigan for undergraduate admissions because] they get their racially diverse results without saying directly what they are doing or why they are doing it." ${ }^{15}$

Justice Ginsburg's point could come back to haunt proponents of the Plan because facial neutrality of a law is insufficient to render it constitutional under the Equal Protection Clause. Pursuant to the constitutional principle of separation of powers, the judicial branch of government should give substantial deference to legislative and executive action. Consequently, laws the legislative branch enacts will receive a low level of judicial scrutiny unless they draw distinctions based on a suspect classification such as race or sex.

Rational-basis review is the lowest level of constitutional scrutiny. ${ }^{15^{2}}$ It is the standard courts default to when reviewing government action. ${ }^{153}$ Unless the challenged action triggers heightened scrutiny by drawing distinctions based on a suspect classification, or infringing on a fundamental right, the court will apply the rational basis test to determine constitutionality. ${ }^{154}$ Under rational-basis review, courts will uphold a law as long as it is rationally related to a legitimate government purpose. ${ }^{155}$ Courts will subject a challenged facially neutral $\operatorname{law}^{15}{ }^{6}$ that has a disparate impact on a racial group to rationalbasis review unless it imposes a discriminatory impact on that group ${ }^{157}$ and

\footnotetext{
149. Id. at 644 .

15 o. As Justice Ginsberg acknowledged, "Only an ostrich could regard the supposedly neutral alternatives [referring to the Ten Percent Plan] as race unconscious." Fisher v. Univ. of Tex. at Austin (Fisher I), 133 S. Ct. 241 1, 2433 (2013) (Ginsburg, J., dissenting).

151. Gratz, 539 U.S. at 298 (Ginsberg, J., dissenting).

152. ERWIN CHEMERINKSY, CONSTITUIONAL LAW: PRINCIPLES AND POLICIES 694 (4th ed. 2011 ).

153. Id.

154. Id.

155. See Pennell v. City of San Jose, 485 U.S. 1, 13 (1988) ("[W]e have long recognized that a legitimate and rational goal of price or rate regulation is the protection of consumer welfare.").

156. A facially neutral law is one that says nothing about race or any suspect classification in the text of the law. See Hunt v. Cromartie, 526 U.S. 541, 546 (1999).

157. See Palmer v. Thompson, 403 U.S. 217,222 (1971).
} 
has a discriminatory purpose. ${ }^{15^{8}}$ Under the rational-basis test, a court could hold the Plan to be constitutional because it is rationally related to the legitimate state goal of achieving racial and geographic diversity in Texas public higher education.

However, a reviewing court could decide that the Plan triggers strict scrutiny because it arguably has both a discriminatory impact and a discriminatory purpose. A court could hold that the Plan imposes a discriminatory impact on white applicants to Texas colleges by displacing those who have higher SAT and ACT scores than the students of color graduating from predominately black or Latina/o high schools who the Plan admits instead by privileging their high school GPA. A court could also hold that the Texas legislature had a discriminatory purpose when it enacted the law because the legislature's clear intent was to achieve both racial and geographic diversity in Texas public colleges and universities by excluding a significant portion of white applicants whom the elite public universities may otherwise admit. To act with a discriminatory purpose, the legislature must do more than merely know about the discriminatory impact of its law at the time of enactment. Instead, a court must find that the legislative body enacted the law "at least in part 'because of,' not merely 'in spite of,' its adverse effects upon an identifiable group." ${ }_{59}$ A court could find that the Texas legislature adopted the law not merely in spite of its adverse effect on white high school students, but because it would adversely affect them by excluding a significant portion of them from admission at elite colleges.

Despite this vulnerability to characterization as a "racial classification" under equal-protection jurisprudence, the Court has consistently accepted the Plan as a constitutional race-neutral classification that is reviewed pursuant to the rational-basis test. Hence, although a completely colorblind legislature did not enact the Plan, and it is arguably race-conscious because legislators were conscious of its racial implications when it was adopted, it remains a race-neutral classification for purposes of equal-protection law.

The Plan's relatively secure status as race-neutral legislation paves the way for colleges and universities to experiment with race-neutral admissions policies that are conscious of their impact on racial diversity. The next Subpart explores how law schools might exploit this constitutional permission to experiment with race-neutral measures that are conscious of racial impact in their efforts to assemble a diverse study body and comply with Fisher I.

\section{B. USING RACE-NEUTRAL CRITERIA IN LAW-SCHOOL ADMISSIONS TO ACHIEVE RACIAL DIVERSITY}

For law schools that interpret the mandate to consider race neutral alternatives as more than a mandate to think about it, the findings of our study offer one method to test the viability of race neutrality in law school admissions. To be clear, the findings from this study do not prove that law

\footnotetext{
158. See Washington v. Davis, 426 U.S. 229, 239-40 (1976).

159. Pers. Adm'r of Mass. v. Feeney, $44^{2}$ U.S. $25^{6,} 279$ (1979).
} 
schools can achieve a critical mass of students from underrepresented groups using race neutral admission policies. Instead, the findings from this study equip law schools with data that can be used to test the viability of race neutral admissions in a particular law school context.

\section{Law Schools Have a Unique Opportunity to Experiment with Race Neutrality}

Researchers have conducted several studies to determine whether the socioeconomic status of a college applicant, determined by household income of his or her parents, could potentially benefit universities seeking to achieve both economic and racial diversity if they weigh it as a factor in their admissions processes. Proponents of this form of wealth-based affirmative action view it as fairer than race-conscious affirmative action because it does not draw distinctions between people based on the practice of classifying them by race, and it would help the people whom they perceive as needing and deserving the benefit of affirmative action get into elite colleges. Proponents of class-based affirmative action argue that race-conscious affirmative action benefits primarily affluent privileged blacks and other privileged racial minorities while helping only a few poor racial minorities. ${ }^{160}$ They frequently reference Barack and Michelle Obama's daughters as the exemplar of affluent blacks who do not need or deserve any form of raceconscious affirmative action to get into college. ${ }^{161}$

This critique of race-conscious affirmative action argues that it is unfair to have a policy aimed at benefitting affluent and already privileged individuals from certain racial minority groups over the underprivileged members of all races. ${ }^{162}$ Indeed, when educational institutions first implemented race-conscious affirmative action in the 196os, the primary beneficiaries were African-Americans who were the first in their families to attend college ${ }^{163}$ and whose parents had endured segregation laws and other forms of purposeful discrimination trampling asunder their own educational and employment goals. The current generation of college applicants contains the children and grandchildren of the first-generation beneficiaries of affirmative action, affording many of them two college-educated parents and

16o. See generally Deborah C. Malamud, Affirmative Action, Diversity, and the Black Middle Class, 68 U. COLO. L. REV. 939 (1997); see also supra note 41 and accompanying text.

161. This argument ignores the reality that children from politically powerful and wealthy families have other forms of affirmative action to help them get into the colleges of their choice, such as receiving a legacy preference due to their parents having attended the school or a donor preference due to their parents' financial contributions to the school. When ABC's George Stephanopoulos asked President Obama whether his "daughters deserved affirmative action in college admissions, Obama replied that" they didn't and asserted that "his daughters should 'be treated by any admissions officer as folks who are pretty advantaged.' Richard Kahlenberg, The Affirmative Action Trap, AM. PROSPECT (Apr. 1, 2010), http://prospect.org/article/affirmativeaction-trap-o.

162. See Malamud, supra note 160 , at 988-96 (discussing the continued need for affirmation action to help those within the black middle class).

163. Richard SANDER \& StUART TAYlor, JR., Mismatch: How AFFiRMATIVE ACTION Hurts STUDENTS IT'S INTENDED TO HELP, AND WHY UNIVERSITIES WON’T ADMIT IT 28 (2012). 
elite academic preparation at the primary and secondary level. ${ }^{164}$ Moreover, with the legalization of interracial marriage in $1967,{ }^{165}$ many applicants who check the "black box" and receive consideration as people who would increase racial diversity are biracial Americans who have, to some extent, enjoyed the benefits of white privilege. ${ }^{166}$ Conversely, some proponents of affirmative action criticize the way educational institutions implement raceconscious affirmative action because they believe it has become dislodged from its historical moorings of seeking to redress past racial injustice against African-Americans. They point to the fact that a significant percentage of applicants benefitting from race-conscious affirmative action at elite public universities are foreign-born blacks who did not suffer the intergenerational harms of slavery and Jim Crow, and arguably displace African-Americans from educational opportunities. ${ }^{167}$ Thus, opponents and proponents of raceconscious affirmative action advocate for its abandonment or retooling so that it benefits more economically disadvantaged students. Underperforming public primary and secondary schools are more likely to educate students from low-income households, which leaves these students underprepared to perform well on college entrance exams. ${ }^{168}$ As a result, standardized test scores on the SAT and ACT correlate, with statistical significance, to the socioeconomic status of high-school student applicants to college. ${ }^{169}$ Consequently, students from low-income families are more likely to score lower than what is necessary to compete for and secure a place in the entering class at many elite public colleges. At Michigan, for example, only $13 \%$ of the undergraduate population received Pell Grants ${ }^{17^{\circ}}$ from the federal government. Because the government awards these grants only to undergraduate students from low-income families ${ }^{171}$ they serve as a good

\footnotetext{
164. Id.

165. Loving v. Virginia, 388 U.S. 1 (1967).

166. See Brown \& Bell, supra note 45 , at $1245^{-54}$; see also infra note 187 . For an understanding
} of white privilege, see Peggy McIntosh's groundbreaking essay identifying the various ways that her whiteness operates to privilege her in daily life such as being able to walk into any hair salon and find a hair stylist who can deal with her hair and being able to shop alone without store personnel following or harassing her. Peggy McIntosh, White Privilege and Male Privilege: A Personal Account of Coming to See Correspondences Through Work in Women's Studies, in POWER, PRIVILEGE AND LAW: A CIVIL Rights READER 2 2, 25-27 (Leslie Bender \& Daan Braveman eds., 1995). For more on white privilege, see Paula S. Rothenberg, White Privilege: Essential Readings on the OTHER SIDE OF RACISM 95-119 (2005).

167. See, e.g., Brown \& Bell, supra note 45, at 1249-54; Onwuachi-Willig, supra note 45, at $1145^{-5}$.

168. See Green, supra note 144, at 139-40.

169. LANi GUINIER, THE TYRANNY OF THE MERITOCRACY: DEMOCRATIZING HigHER EDUCATION IN AMERICA 52 (2015); LANI GUINIER \& GERALD TORRES, THE MINER'S CANARY: ENLISTING RACE, RESISTING POWER, TRANSFORMING DEMOCRACY 68 (2002).

170. Ellen Berrey, The Enigma of Diversity: The Language of RACE AND the Limits OF RACIAL JUSTICE $96(2015)$.

1 7 1. Most students receiving a Pell Grant are from families earning less than $\$ 80$,ooo per year. See generally U.S. DeP'T OF EDUC., FEDERAL PELl GRANT PROGRAM ANNUAL DATA RePORTS (2014-2015), https://www2.ed.gov/finaid/prof/resources/data/pell-2014-15/pell-eoy-2014-15.html (listing the number of recipients each year by income bracket). 
indicator of the economic diversity in the student body of an undergraduate institution. Because economically disadvantaged students have a clear need not only in the financial arena but also in finding opportunities to attend elite colleges, opponents of race-conscious affirmative action have a persuasive argument for restructuring affirmative action to benefit this group.

Opponents of class-based affirmative action see this type of reform as a means of excluding more racial minorities from elite higher education. Because there are so many more poor whites than poor minorities in the United States, and because the size of a class-based preference in admissions at elite schools would have to be very large to yield admission of low income minority students, prior studies on the use of class-based affirmative action suggest that this approach may result in fewer racial minorities attending elite colleges and lower academic credentials of admitted students. ${ }^{172}$ Despite these concerns, considering students' socioeconomic status in admissions decisions has contributed to racial diversity on college campuses, albeit not to the same extent as race-conscious measures. ${ }^{173}$ Because a disproportionate number of students of color come from low-income households, this race-neutral approach to affirmative action is still race-conscious, and law schools can use it to create racially diverse student bodies.

Like other scholars who have examined the Equal Protection Clause in the educational context, we see it as having the anti-subordination purpose of eliminating racial caste. ${ }^{174}$ An affirmative-action policy that perpetuates the existing stratification of racial minorities in law school by relegating the overwhelming majority of them to less prestigious institutions would serve to entrench white racial dominance in the legal profession further. Ignoring race in law-school admissions altogether would likely have this effect and fail to preserve the anti-subordination principle embedded in the Equal Protection Clause. We assert that affirmative action in the law-school context can be both race-blind and race-conscious, much like the Texas Ten Percent Plan. Some law schools may be able to abandon the use of race in their admissions and continue to yield a critical mass of racial diversity by using socioeconomic questions that align closely with the racial diversity they seek

172. See generally Ben Backes, Do Affirmative Action Bans Lower Minority College Enrollment and Attainment?: Evidence from Statewide Bans, 47 J. HuM. RESOURCES 435 (2012) (finding that after statewide bans on considering race in college admissions, black and Hispanic enrollment dropped at the top institutions in those states); Mark C. Long, Is There a "Workable" Race-Neutral Alternative to Affirmative Action in College Admissions?, 34J. POL'Y ANALYSIS \& MGMT. 162 (2015) (asserting that in the college admissions context, "a system that uses an applicant's predicted likelihood of being an underrepresented racial minority as a proxy for the applicant's actual minority status can yield an admitted class [with] a lower predicted [GPA]" than the class would have had if race had been considered in the admissions process).

173. See Eboni S. Nelson, What Price Grutter? We May Have Won the Battle, but Are We Losing the War?, 32 J.C. \& U.L. 1, $4^{1}$ (2005) ("[C]ollege and university consideration of applicants' socioeconomic background has helped to increase their diversity levels.").

174. Lia Epperson, Equality Dissonance: Jurisprudential Limitations and Legislative Opportunities, 7 StAn. J. Civ. RTS. \& CIV. Liberties 213 , $213^{-1} 4$ (2011) (noting that the Court in Parents Involved embraced an anti-subordination definition of the equal protection clause and found that the elimination of racial isolation in public schools was a compelling governmental interest). 
to achieve. In so doing, they may be able to disprove the class-versus-race dichotomy in affirmative action by asking applicants socioeconomic related questions about their identity in lieu of asking their race and then weighting the application of students who fit an established socioeconomic profile.

For example, our study found that African-American students were the most likely to provide uncompensated service to racial groups that are underserved by the legal profession. Because law schools should want to do their part in closing the access-to-justice gap, they could appropriately weight the applications of applicants who provide documentation of uncompensated service to racial groups that the legal profession underserves. Our study suggests that redefining merit in this way would benefit African-American applicants to law school and possibly help law schools matriculate more African-American students than asking applicants about their race. Asking applicants to report this type of service would also send a message that the schools value it and incentivize others to perform service to these groups.

Law school is a uniquely fertile testing ground for this type of experimentation because, unlike an undergraduate school where applicants could game the system by answering questions on an admissions application in a way that they think will curry favor, law-school applicants must be truthful on their applications. This is partly because they are applying to become part of a profession that highly values ethics, ${ }^{175}$ but also because the Bar authorities subsequently verify the answers on their application when they apply to take the Bar examination. We set out to explore what set of race-neutral socioeconomic questions law schools could ask on the application, in lieu of race, that might yield significant racial diversity in their student bodies. ${ }^{17^{6}} \mathrm{We}$ also sought to explore, briefly, whether racial diversity in law school classrooms brought different viewpoints to law school classrooms.

175. The Bar expects high moral character of all persons seeking admission. For a discussion of moral character as a professional credential, see Carla D. Pratt, Should Klansmen Be Lawyers?: Racism as an Ethical Barrier to the Legal Profession, 30 FLA. ST. U. L. REV. 857, 864-67 (2003); and Deborah L. Rhode, Moral Character as a Professional Credential, 94 YALE L.J. 491, 507-08 (1985).

176. We recognize that there will be differing views among faculty members in law schools regarding the proper approach to take to enrolling a diverse class. Some law school deans and faculty members want to move away from considering race in admissions in an effort to insulate their schools from legal challenges; others want to use race-blind admission because they object to racial consideration as improper. Other law school deans and faculty members will want to continue to use race to achieve a racially diverse class. We anticipate that law schools might experience some interest convergence among faculty members with differing views. Faculty members on both sides of the affirmative-action equation may decide to use our study to test the viability of race-blind admissions, but for different reasons. Faculty members who are opposed to the use of race might opt for trying a race-blind admission cycle hoping to move the institution away from racial consideration, whereas those who favor using race in admissions might opt for trying a race-blind admission cycle in order to obtain evidence that shows that it is not as effective in achieving a racially diverse student body as the consideration of race, or in order to demonstrate compliance with Fisher I. 


\section{Study Design}

This study sought to determine race-neutral identity factors that align closely with the socially mapped racial groups that enter law schools each year. We sought to design a study that would inform the law-school admissions process and help law schools test whether they could seat a racially diverse student body without asking applicants about their race. The ability to seat a racially diverse student body without asking about race is important for three reasons. First, having a race-blind tool to help identify students who will contribute to student-body diversity is essential for law schools operating in jurisdictions that ban racial consideration in higher education admissions decisions. ${ }^{177}$ Second, having a race-blind tool is helpful to law schools in jurisdictions that do allow racial consideration in law school admissions because identifying race-neutral identity factors that law schools can ask about on their applications provides them with a means ${ }^{17}{ }^{8}$ to "consider" race-blind admissions as Fisher I requires. ${ }^{179}$ Our study will provide useful information to law schools that may be interested in experimenting with a race-blind admission cycle in an effort to determine whether the school could yield a critical mass of racial minority students if it moved to a race-neutral admissions process. Finally, with the continued constitutional attacks on race-conscious admissions practices, a race-neutral admissions tool may become a necessity for all law schools seeking to seat a diverse student body if the Supreme Court restricts the use of race in higher-education admissions in the future. ${ }^{180} \mathrm{We}$ were the investigators in the study. We are wholly responsible for the study's design and implementation. We collectively designed the survey instrument that study participants completed ${ }^{181}$ by first conducting a literature review to determine the social and economic aspects of life that disproportionately impact people of color. We used that literature to develop survey questions related to personal identity. ${ }^{182}$ For example, the literature on education shows

177. Presently, eight states ban race-conscious affirmative action in higher-education admission: Florida, New Hampshire, California, Washington, Michigan, Nebraska, Arizona, and Oklahoma. See Affirmative Action: State Action, NAT'L CONF. ST. LEgisLATURES (Apr. 2014), http://www.ncsl.org/research/education/affirmative-action-state-action.aspx.

178. We do not assert that our study is the only means by which a law school could experiment with the viability of race-neutral admissions. We assert that it is merely one way that law schools can fulfill the mandate of Fisher I, which is to consider race-neutral alternatives to asking applicants to identify their race in the admissions application process.

179. See supra notes 131-34 and accompanying text.

180. See generally Fisher v. Univ. of Tex. at Austin (Fisher II), 136 S. Ct. 2198 (2016).

181. See Appendix A.

182. Rebecca Goldring et Al., NAT'L Ctr. FOr Educ. Statistics, Characteristics of Public AND PRIVATE ELEMENTARY AND SECONDARY SCHOOL TEACHERS IN THE UNITED STATES: RESUlTS FROM THE 2011-12 SCHOOLS AND STAFFING SURVEY (2013) https://nces.ed.gov/pubs2013/2013314.pdf (Survey Question B-1). We have known since at least 1978 that the racial composition of high schools impacts college attendance and test performance. See ROBERT L. CRAIN \& RITA E. MAHARD, RAND CORP., THE INFLUENCE OF High SCHOOL RACIAL COMPOSITION ON BLACK COLLEGE ATTENDANCE AND Test PERFORMANCE (1978), http://nces.ed.gov/pubs78/782 12.pdf (Survey Question B-2; a national longitudinal study); see also Discrimination in Education, $85^{\text {th }}$ Session of the Committee on the Elimination of All Forms of Racial Discrimination, Geneva (Aug. 2014) (documenting the continued 
racial subordination of children of color who are victims of de facto racial segregation in public education); Katherine Ralston ET AL., U.S. DeP'T OF AgRic., The NATIONAL SCHOOL LunCH PROGRAM: BACKGROUND, TRENDS, AND IsSUES (2008) (Survey Question B-3).

Eligibility for the free and reduced-price lunch program is often used as a proxy measure of family income .... Overall, 41 percent of $4^{\text {th-graders were eligible for }}$

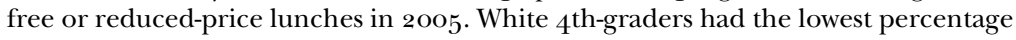
of eligible students (24 percent). The percentages of Black and Hispanic $4^{\text {th-graders }}$ ( 70 and 73 percent) who were eligible were three times the percentages of White $4^{\text {th-graders }}$ who were eligible, and the percentage of American Indian/Alaska Native $4^{\text {th-graders }}$ (65 percent) who were eligible was nearly three times that of Whites. Asians/Pacific Islanders also had a higher percentage (33 percent) of eligible students than did Whites, but a lower percentage than did Blacks, Hispanics, or American Indians/Alaska Natives.

NAT'L CTR. FOR EDUC. STATISTICS, Status and Trends in the Education of Racial and Ethnic Minorities: Indicator 7: Elementary and Secondary Enrollment (Sept. 2007) (citation omitted), https://nces.ed.gov/ pubs2007/minoritytrends/ind_2_7.asp; Teresa L. Morisi, Youth Enrollment and Employment During the School Year, MONTHLY LAB. REV. 51, $5^{8}$ (2008) (Survey Question B-4); see also generally CHILD TRENDS DATABANK, YOUTH EMPLOYMENT: INDICATORS ON CHILDREN AND YOUTH, http:/ /www.childtrends.org/ wp-content/uploads/2012/05/120_Youth_Employment.pdf (last updated Dec. 2015). As recent as the 2013-14 school year, only 73 percent of black public high school students and 76 percent of Hispanic public high school students graduated on time with a regular diploma. NAT'L CTR. FOR EDUC. Statistics, The Condition of Education: Public High School Graduation Rates (last updated May 2016), http://nces.ed.gov/programs/coe/indicator_coi.asp (Survey Question B-5). This achievement gap has existed for decades, which suggests that minority law school applicants and law students who are from black and/or Hispanic households are more likely to have parents who did not complete high school. Id.; XIAOJIE LI, NAT'L CTR. FOR EdUC. STATISTICS, CHARACTERISTICS OF MiNORITY-SERVING INSTITUTIONS AND MINORITY UNDERGRADUATES ENROLLED IN THESE INSTITUTIONS: POSTSECONDARY EDUCATION DESCRIPTIVE ANALYSIS REPORT $3^{8}$ (2007), http://nces.ed.gov/pubs20o8/2008156.pdf (Survey Question B-6). Oliver and Shapiro document the wealth gap between black and white families and the primary causes for that gap. They point out that black families earn lower incomes and suffer higher unemployment rates, which suggests that black law-school applicants and black law students may have had to work for money in college more than non-black college students. MELVIN L. OLIVER \& Thomas M. Shapiro, Black WeALTh/White WEALTH: A NEW PERSPECTIVE ON RACIAL INEQUALITY (1995) (Survey Question B-7) [hereinafter BLACK WEALTH/WHITE WEALTH]. Evensen and Pratt found that black law students reported having to work for money to get through college and law school. See generally Green, supra note 144 (Survey Question B-8); see also generally MARK KANTROWITZ, STUDENT Aid POLICYANALYSIS, The Distribution OF GRANTS AND SCHOLARSHIPS By RACE (201 1). Susan P. Choy, Students Whose Parents Did Not Go to College: Postsecondary Access, Persistence, and Attainment, in THE CONDITION OF EDUCATION 6 (2001) (Survey Question B-9); see generally Green, supra note 144 (Survey Question B-10; suggesting that many black law students are the first in their immediate family to attend law school, and many black law-student participants in the study reported not even knowing a black lawyer before going to law school). See Carla D. Pratt, Way to Represent: The Role of Black Lawyers in Contemporary American Democracy, 77 FORDHAM L. REv. 1409, $143_{1}$ (2009) (Survey Question B-1 1; noting that black culture socializes people to have a sense of responsibility to give back to their black communities, which is why many black lawyers devote their philanthropic efforts toward the less fortunate living in black communities). KIDS COUNT DATA CTR., CHILDREN IN SINGLE-PARENT FAMILIES BY RACE, http:/ / datacenter.kidscount.org/data/tables/107-children-in-single-parent-families-byrace?loc $=1$ \&loct= 1 \#detailed $/ 1$ / any/false $/ 869,36,868,867,133 / 10,1$ 1,9, 1 2,1,1 85,1 3/432,431 (last updated Jan. 2017) (Survey Question C-1). ROSE M. KREIDER \& RENEE ElliS, U.S. CENSUS BUREAU, LIVING ARRANGEMENTS OF CHILDREN: 2009: HOUSEHOLD ECONOMICSTUDIES ( 2011 ) (Survey Question C-2). Teresa Wiltz, Racial and Ethnic Disparities Persist in Teen Pregnancy Rates, Pew Charitable Trusts: STATELINE (Mar. 3, 2015), http://www.pewtrusts.org/en/research-and-analysis/blogs/stateline/ $2015 / 3 / 03 /$ racial-and-ethnic-disparities-persist-in-teen-pregnancy-rates (Survey Question C-3).

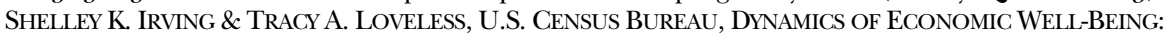
PARTICIPATION IN GOVERNMENT PROGRAMS, 2009-2012: WHO GETS ASSISTANCE?: HOUSEHOLD ECONOMIC STUDIES (2015) (Survey Question C-4). Oliver and Shapiro, in their study of white family 
that a large portion of children of color are educated in the public-school system. ${ }^{183}$ Consequently, we formulated identity-related questions about the

wealth and black family wealth, have consistently documented that annual household income for black families is on average less than annual household income for white families. Consequently, we anticipated that family income for black, Native American and Hispanic law-school applicants might be considerably less than family income for whites. See BLACK WEALTH/WHite WEALTH, supra (Survey Question $\mathrm{C}_{-5}$ ). We asked about family income while study participants were in high school because family income at that time likely would influence the trajectory of the students' education, including where they went to college. Because mass incarceration has had a disparate impact on people of color, we asked about incarceration. We limited the question to immediate family out of fear that the broad sweep of mass incarceration may have touched every American family at some level. See generally Michelle AleXANDER, The NeW Jim CROW: MASS INCARCERATION IN THE AGE OF COLORBLINDNESS (2010) (Survey Questions C-6 and C-7). We asked if students were raised in households that spoke a language other than English, rather than ask about language fluency, because we anticipated that asking about language fluency would capture students who learned another language without a cultural connection to that language and would miss students who had a cultural connection to a language other than English, but whose parents did not teach it to them in an effort to protect them from racial and ethnic discrimination by whites. Available statistics show that "[t]he percentage of public school students in the United States who were English language learners was higher in school year 2013-43 (9.3 percent, or an estimated 4.5 million students) than in 2003-04 (8.8 percent, or an estimated 4.2 million students) and in 2012-13 (9.2 percent, or an estimated 4.4 million students)." Fast Facts: English Language Learners, NAT'L CTR. FOR EDUC. STATISTICS, http:/ nces.ed.gov/fastfacts/ display.asp?id=96 (last visited Apr. 20, 2017) (Survey Question C-8). Religious Landscape Study: Racial and Ethnic Composition, PEw RES. CTR., http://www.pewforum.org/religious-landscape-study/racialand-ethnic-composition (last visited Apr. 20, 2017) (Survey Question C-9). We were cognizant of the fact that the places where students come from often help determine their opportunities, so we asked students to disclose this information. See SHERYLl CASHIN, THE FAILURES OF INTEGRATION: How RACE AND CLASS ARE UNDERMINING THE AMERICAN DREAM 3-4 (2004). See generally CASHIN, supra note 145 (Survey Question C-10; arguing that affirmative action should move away from race and toward "place" to locate its intended beneficiaries). KIDS COUNT DATA CTR., Children Living in Areas of Concentrated Poverty by Race and Ethnicity, http://datacenter.kidscount.org/data/tables/7753-children-living-inareas-of-concentrated-poverty-by-race-and-ethnicity?loc $=1$ \&loct $=1$ \#detailed $/ 1$ /any $/$ false $/ 1485,1376,1$ 201,1074,880/10,11,9,12,1,185,13/14943,14942 (last updated Jan. 2017) (Survey Question C-1 1). Questions were added to assess the views of student participants regarding the importance of diversity in the classroom. While the Supreme Court and various educators have asserted the importance of diversity, we wanted to take this opportunity to get the opinion of the people who were experience education in law school classrooms. Since the goal of the study is to provide law schools with tools for achieving diversity in law school classrooms, we thought the survey was a good opportunity to assess the students' views about the importance of diversity in the law school classroom. Some of the questions eliminate "race" from the diversity calculus in an effort to identify whether law students value raceneutral forms of diversity over racial diversity. We know from existing literature that the general population has different views about race-based affirmative action with blacks favoring it at a much higher rate than whites, but we were not sure whether this racial dichotomy of viewpoint would hold up in the "diversity in law school" context. Conflicted Views of Affirmative Action: Summary of Findings, PEW RES. CTR. (May 14, 2003), http://www.people-press.org/2003/05/14/conflicted-views-of-affirmativeaction (Survey Questions D-1 through D-4).

183. "Black students are six times more likely to attend high-poverty" low-performing public schools with $45 \%$ of black students attending these schools compared to only $7 \%$ of white students. Tanvi Misra, The Stark Inequality of U.S. Public Schools, Mapped, CITYLAB (May 14, 2015), http://www.citylab.com/housing/2015/05/the-stark-inequality-of-us-public-schools-mapped/393 095. U.S. Department of Education data show that non-white school aged children attending private schools is around $30 \%$ of the overall private school population and $69.6 \%$ of school aged children in private schools are white. See NAT'L CTR. FOR EDUC. STATISTICS, https://nces.ed.gov (last visited Apr. 20, 2017). Moreover, the National Center for Education Statistics reports:

From fall 2003 through fall 2013 , the number of White students enrolled in public elementary and secondary schools decreased from 28.4 million to 25.2 million, and 
nature of the $\mathrm{K}-12$ education that student participants received. The literature we relied upon to develop the survey questions focused on studies involving the general population. As a result, we were not sure whether the findings of this literature were transferrable to a relatively privileged subset of the general population, such as law students. ${ }^{184}$ Administering the survey to first-year law students will inform our understanding of whether there are social identity factors that align more closely with law students of certain racial groups.

Our construction of the survey instrument was also informed by the theory of intersectionality. ${ }^{185}$ The theory of intersectionality originates from critical-race theory and posits that some individuals reside at the intersection of more than one subordinated identity. ${ }^{186} \mathrm{~A}$ black woman, for example, exists at the intersection of her subordinated racial identity and her subordinated gender identity. Her experience as a person whose identity exists at the intersection of two subordinated identity factors is therefore different from a white woman's experience who endures subordination of her gender identity but enjoys the benefits of racial privilege. Just as an individual may have an identity that exists at the intersection of more than one subordinated identity, there may be certain social identity factors that intersect with one another more often than others. In other words, the theory of intersectionality alerted us to the possibility that a cluster of identity factors that align with a particular race more closely than other races may exist. Through analysis of the survey data, we seek to identify which identity factors individually align closely with each racial group. We also seek to understand and identify whether there are

\footnotetext{
the percentage of students who were White decreased from 59 to $5^{\text {o percent. In }}$ contrast, the number of Hispanic students enrolled during this period increased from 9.o million to 12.5 million, and the percentage who were Hispanic increased from 19 to 25 percent. The number of Black students enrolled decreased from 8.3 million to 7.8 million, and the percentage who were Black decreased from 17 to 16 percent. Since fall 2002, the percentage of students enrolled in public schools who were Hispanic has exceeded the percentage who were Black. Additionally, the number of American Indian/Alaska Native students enrolled from fall 2003 to fall 2013 decreased from 0.6 million to 0.5 million, and the percentage who were American Indian/Alaska Native remained around 1 percent. The number of White students enrolled in public schools is projected to continue decreasing between fall 2014 and fall 2025 (from 25.0 million to 23.5 million) and to account for 46 percent of total enrollment in 2025 .
}

Racial/Ethnic Enrollment in Public Schools, NAT'L CTR. FOR EDUC. STAT., https://nces.ed.gov/ programs/coe/indicator_cge.asp (last updated May 2016).

184. Law students are a privileged group in that they generally have achieved at least a bachelor's degree and have demonstrated academic and non-academic achievements that earn them admission to law school. In the $2014^{-1} 5$ academic year, there were 54,467 applicants to ABA approved U.S. law schools and only 35,726 of those applicants matriculated to law school. LAW SCHOOL Admissions COUnCIL, US NATIONAL DECISION PrOFIles-FALl TERM 2014-2015 APPLICATION YEAR SUMMARY (2016), http://www.lsac.org/docs/default-source/data-(members)/ national-decision-profiles-fall-2015.pdf.

185. See Kimberlé Williams Crenshaw, Demarginalizing the Intersection of Race and Sex: A Black Feminist Critique of Antidiscrimination Doctrine, Feminist Theory, and Antiracist Politics, in CRITICAL RACE FEMINISM: A READER 23 (Adrien Katherine Wing ed., 2d ed. 2003).

186. Id. 
individual identity factors that intersect in a meaningful way to bring the relationship with a particular racial group even closer to that particular identity factor. If certain identity factors intersect in a way to heighten their relationship to a particular racial group, law schools could potentially use that subset of identity related questions on their applications to conduct race-blind admissions that yield a critical mass of students from racial groups that are underrepresented in law schools and the legal profession.

In addition to questions related to identity, the survey also contains four questions related to viewpoint. Law schools seeking to conduct race-blind admissions could not use these opinion-based questions in their applications because applicants would likely proffer answers that they think the law school would value since opinions are not facts that can be verified by bar authorities. Consequently, we added these questions to the survey to help law schools understand the perceived value of diversity in their individual institutions and whether minority students bring viewpoints to their classrooms that differ significantly from viewpoints of white students. We framed the four questions in the context of diversity in an effort to determine whether students value a diverse learning environment and whether there are differences in student views that align with race.

Overall, this study is exploratory in nature; thus, we do not posit any specific research hypotheses. We do, however, examine this research question: Is there a relationship between law-school students' racial/ethnic background and their reported identification with race-neutral identity factors?

\section{Data Collection}

We restricted data collection to first-year law students enrolled at public ABA approved law schools in jurisdictions that presently permit raceconscious affirmative action in higher education. We restricted the study to first-year students who have matriculated to law school because they provide the most recent example of students willing to attend law school in general and the law school that enrolled them in particular. We considered, but rejected, a study design surveying applicants to law schools because applicants would be harder to reach and many applicants overlap with multiple law schools, so using matriculants instead of applicants avoids the problem of inviting the same applicant to complete the survey more than once. Because we administered the survey to anonymous participants, if we surveyed applicants instead of matriculants we would have had no reliable means of protecting against duplication in the completion of the survey.

We restricted participation to public law schools in jurisdictions that permit racial consideration in admissions because we anticipated that law schools in those jurisdictions would be more likely to have more diversity in their student body and specifically more students of color. Public law schools in jurisdictions that permit racial consideration in law school admissions are also more vulnerable to suit by a challenger if they employ race-conscious affirmative action. Consequently, we thought this group of law schools could benefit from their students' participation in the study. 
We sought to administer the survey to law students at a cross-section of public ABA approved U.S. law schools. We identified this cross-section by considering the geographical region of the United States where the law school is located, the campus setting in which it is situated (such as urban, suburban or rural), its size, and its U.S. News $\mathcal{E}$ World Report ranking. We used these lawschool identity factors to ensure that the study would capture a diverse group of law schools because we recognized that student social and economic identity factors may present and operate differently at a top-ranked urban law school than at a lower-ranked law school in a rural setting.

To secure participating schools, our research team sent an invitation letter to the dean at each public ABA approved law school inviting them to have their law school participate in the study. After securing the commitment of several deans, we followed up with individual deans at law schools that would help us meet the cross-section requirements identified above. We sought to have between 10 and 12 law schools in our sample so that, with an average of 100 student participants per law school, we would have a dataset with approximately 1 ,ooo survey participants if we had a high participation rate among students. To avoid conflict of interest issues, we rejected the idea of a financial incentive to induce a high participation rate of students at each law school and instead asked deans to permit us to administer the survey during a time when the first-year class convened for some other purpose, such as orientation, a speaker, or a course. This proved to be a successful method for achieving a high participation rate $(88 \%)$ among first year students at participating law schools.

This study's design is not without limitations. Using a survey instrument creates an interpretation challenge because, despite careful wording of questions, not all participants will interpret the survey questions the same way. Moreover, our survey captures some identity characteristics, but not all, so there will undoubtedly be areas of social identity that we do not cover-but that may nonetheless align closely with race. Our survey, like all surveys, is subject to the reality that some participants may choose to answer falsely. Because we are surveying current law students in the process of indoctrination into a profession that emphasizes ethics, we think the risk of participant sabotage is probably less than in surveys administered to the general population. Likewise, the survey is subject to biases in that some participants may recall certain information about themselves or their families in a way that is filtered through their own cognitive biases. It is impossible to eliminate these drawbacks from survey-based research, and they are not significant enough to invalidate it.

\section{Data Analysis}

We used descriptive statistics (e.g., frequencies and percentages) to highlight demographic information, such as the number of students at each law school. We also used descriptive statistics to illustrate how many students in each racial or ethnic group endorsed race-neutral items on the survey. This information is important because it provides a visual overview of which raceneutral factors participants endorsed more and which they endorsed less. 
These analyses also allow for a cursory comparison between the racial or ethnic groups on which race-neutral factors they endorsed.

We used inferential statistics to examine the more complex question in this study (i.e., "Is there a relationship between law school students' racial/ethnic background and their willingness to endorse race-neutral identity factors?"). Examining each race-neutral item on the survey in isolation can be informative. However, it is often the case that a single item on a survey does not provide sufficient information about race neutrality, nor does it allow for inferences about what it means if, for example, African-American students endorse a race-neutral item at a much higher rate than white students. However, when several race-neutral items on a survey can be added together to make a single item, then this provides a more complex story about race-neutral factors. More importantly, by combining items, it is possible to conduct more complex analyses and draw more meaningful inferences from them. To examine whether any of the items on our survey were conceptually related with one another, we conducted factor analyses on two key survey sections: student background and family background. We then created composite variables by combining all conceptually related items. These composite variables are important because they have a scoring range from low to high so that the higher participant scores on them, the more he or she endorses them.

By creating composite variables of the race-neutral survey items, we were able to report, on average, what each racial or ethnic group scored for each variable. Higher scores denote greater endorsement of that variable, and composite scores also allow for drawing statistically meaningful inferences about differences between groups. For this study, we used analyses of variance ("ANOVA") to examine whether there were statistically significant differences between racial or ethnic groups on the composite variables that we created for the student-background and family-background sections of the survey. This analysis allowed us truly to address our research question in a statistically meaningful way.

It is important to mention that six racial or ethnic groups (i.e., white, African-American, Asian/Pacific Islander, Hispanic, biracial/multiracial, and other) were included in all descriptive analyses because we simply reported the trends in their responses. Participants who identified as biracial or multiracial were those who checked more than one racial or ethnic category (e.g., checking both African-American and Cuban). Participants who identified as other had a greater range of ethnicities, including Italian, German, Arab-American, to name a few. We excluded all participants who identified as biracial or multiracial for all inferential statistics because of methodological concerns. Biracial or multiracial participants checked more than one racial category, which made it difficult to assign them to a category. ${ }^{187}$ Moreover, participants who selected "other" were excluded because they were too heterogeneous to be placed in one category.

187. Considering the current and projected racial demographics of American society and the increasing number of biracial and multiracial students attending institutions of higher 


\section{FINDINGS}

We sampled 10 law schools for this study. Five schools were located in the northeast region of the United States, three in the southern region, and two in the southwestern region. Table 1 provides the racial and gender demographics for each school.

Table 1. Racial and Gender Demographics for First-Year Law Students by Law School

\begin{tabular}{|c|c|c|c|c|c|}
\hline $\begin{array}{c}\text { Law } \\
\text { Schools }\end{array}$ & $\begin{array}{c}\text { Female } \\
\mathrm{n}(\%)\end{array}$ & $\begin{array}{c}\text { White } \\
\mathrm{n}(\%)\end{array}$ & $\begin{array}{c}\text { African- } \\
\text { American } \\
\mathrm{n}(\%)\end{array}$ & $\begin{array}{c}\text { Asian/Pacific } \\
\text { Islander } \\
\mathrm{n}(\%)\end{array}$ & $\begin{array}{c}\text { Hispanic } \\
\mathrm{n}(\%)\end{array}$ \\
\hline LS1 & $\begin{array}{c}71 \\
(38.4 \%)\end{array}$ & $\begin{array}{c}141 \\
(76.2 \%)\end{array}$ & $\begin{array}{c}24 \\
(13.0 \%)\end{array}$ & $\begin{array}{c}5 \\
(2.7 \%)\end{array}$ & $\begin{array}{c}2 \\
(1.2 \%)\end{array}$ \\
\hline LS2 & $\begin{array}{c}29 \\
(44.6 \%)\end{array}$ & $\begin{array}{c}48 \\
(73.8 \%)\end{array}$ & $\begin{array}{c}2 \\
(3.1 \%)\end{array}$ & $\begin{array}{c}8 \\
(12.3 \%)\end{array}$ & $\begin{array}{c}2 \\
(2.1 \%)\end{array}$ \\
\hline LS3 & 45 & 82 & 5 & 2 & 2 \\
$(47.9 \%)$ & $(87.2 \%)$ & $(5.3 \%)$ & $(2.1 \%)$ & $(2.1 \%)$ \\
\hline LS4 & 68 & 100 & 6 & 3 & 12 \\
$(53.1 \%)$ & $(78.1 \%)$ & $(4.7 \%)$ & $(2.3 \%)$ & $(9.4 \%)$ \\
\hline LS5 & $\begin{array}{c}32 \\
(53.3 \%)\end{array}$ & $\begin{array}{c}38 \\
(63.3 \%)\end{array}$ & $\begin{array}{c}9 \\
(15.0 \%)\end{array}$ & $\begin{array}{c}3 \\
(5.0 \%)\end{array}$ & $\begin{array}{c}5 \\
(8.3 \%)\end{array}$ \\
\hline LS6 & 65 & 101 & 5 & 13 & 6 \\
$(45.8 \%)$ & $(71.1 \%)$ & $(3.5 \%)$ & $(9.2 \%)$ & $(4.2 \%)$ \\
\hline LS7 & $\begin{array}{c}34 \\
(48.6 \%)\end{array}$ & $\begin{array}{c}60 \\
(85.7 \%)\end{array}$ & $\begin{array}{c}4 \\
(5.7 \%)\end{array}$ & $\begin{array}{c}1 \\
(1.4 \%)\end{array}$ & $\begin{array}{c}1 \\
(1.4 \%)\end{array}$ \\
\hline LS8 & 73 & 3 & 91 & 1 & 0 \\
& $(65.2 \%)$ & $(2.7 \%)$ & $(81.3 \%)$ & $(0.9 \%)$ & $(0 \%)$ \\
\hline LS9 & 44 & $5 \%$ & 6 & 6 & 8 \\
& $(48.9 \%)$ & $(55.6 \%)$ & $(6.7 \%)$ & $(6.7 \%)$ & $(8.9 \%)$ \\
\hline LS10 & 43 & 78 & 3 & 0 & 1 \\
& $(48.3 \%)$ & $(87.6 \%)$ & $(3.4 \%)$ & $(0 \%)$ & $(1.1 \%)$ \\
\hline
\end{tabular}

Note: "LS" denotes law school.

The majority of the law schools had slightly more male than female firstyear students. Moreover, with the exception of LS 8 and LS 9, over $70 \%$ of the first-year student body identified as white. LS 8 had more African-American students $(81.3 \%)$ than other schools, LS 4 had more Hispanic students $(9.4 \%)$, and LS 2 had more Asian/Pacific Islander students

education, an important future area of study will be to examine the extent to which biracial and multiracial students endorse race-neutral identity factors and whether their endorsements differ from those made by whites and other minority students. See Brown \& Bell, supra note 45, at 1234 n.9 (noting the number of American citizens who self-identified as multiracial in the 20oo Census and the racial categories with which they identified). As Professors Brown, Bell and OnwuachiWillig have demonstrated, examining students' racial and ethnic backgrounds, particularly those admitted to institutions employing affirmative action, has important implications for student diversity in higher education. See id. at 1242-54; see also Onwuachi-Willig, supra note 45 , at 1143 (discussing the importance of considering "the actual ethnic backgrounds or ancestral heritages of . . students"). 
$(12.3 \%)$. Overall, there were 1,035 participants in this study (white $[\mathrm{n}=701$, $72.4 \%$ ], African-American $[\mathrm{n}=155,16.0 \%]$, Asian/Pacific Islander $[\mathrm{n}=42$, $4.3 \%]$, Hispanic $[\mathrm{n}=39,4.0 \%]$, Biracial/Multiracial $[\mathrm{n}=67,6.5 \%]$, and other $[\mathrm{n}=31,3.2 \%])$.

Our goal for this study was not to compare the ten law schools, but rather to aggregate the data from each school to conduct a more comprehensive examination of the use of race-neutral factors in law schools generally. We report all subsequent analyses and findings on this aggregated data. As mentioned earlier, we divided the survey into questions about student educational backgrounds and family background. It was important to first examine trends in data regarding which race-neutral factors each racial or ethnic group endorsed. Table 2 presents the descriptive statistics for each race-neutral student-educational-background survey item, broken down by racial or ethnic group. Although racial or ethnic groups are similar on some race-neutral items, they differ on others. Overall, African-American and Hispanic students endorsed more race-neutral student educational background items (e.g., going to high schools that had a majority of racial or ethnic minorities, receiving free or reduced lunches in high school, receiving Pell Grants as undergraduates) than did other racial or ethnic groups. African-American students were the most likely to report high levels of uncompensated service to racial groups that the legal profession underserves. White and Asian/Pacific Islander students were least likely to endorse raceneutral student educational background items. 
Table 2. Descriptive Statistics for Survey Items Focused on Race-Neutral Student Educational Background

\begin{tabular}{|c|c|c|c|c|c|c|}
\hline & White & Afr/Am & $\begin{array}{l}\text { Asian/ } \\
\text { PI }\end{array}$ & Hispanic & $\begin{array}{c}\mathrm{Bi} / \text { Multi- } \\
\text { Racial }\end{array}$ & Other \\
\hline Public H.S. & $\begin{array}{c}76.2 \\
(\mathrm{n}=532) \\
\end{array}$ & $\begin{array}{c}87.5 \% \\
(n=133) \\
\end{array}$ & $\begin{array}{l}81.0 \% \\
(\mathrm{n}=34)\end{array}$ & $\begin{array}{l}76.9 \% \\
(\mathrm{n}=30)\end{array}$ & $\begin{array}{l}70.1 \% \\
(\mathrm{n}=47) \\
\end{array}$ & $\begin{array}{l}83.9 \% \\
(\mathrm{n}=5)\end{array}$ \\
\hline $\begin{array}{c}\text { Racial } \\
\text { Minorities } \\
\text { Majority of } \\
\text { H.S. }\end{array}$ & $\begin{array}{l}10.3 \% \\
(n=68)\end{array}$ & $\begin{array}{l}37 \cdot 3 \% \\
(\mathrm{n}=53)\end{array}$ & $\begin{array}{l}16.7 \% \\
(\mathrm{n}=6)\end{array}$ & $\begin{array}{l}5^{0.0 \%} \\
(\mathrm{n}=17)\end{array}$ & $\begin{array}{l}28.6 \% \\
(n=16)\end{array}$ & $\begin{array}{r}22.2 \% \\
(\mathrm{n}=6)\end{array}$ \\
\hline $\begin{array}{c}\text { Free/ } \\
\text { Reduced } \\
\text { Lunch } \\
\end{array}$ & $\begin{array}{l}14.9 \% \\
(\mathrm{n}=99)\end{array}$ & $\begin{array}{l}45 \cdot 9 \% \\
(n=68)\end{array}$ & $\begin{array}{l}9.5 \% \\
(\mathrm{n}=4)\end{array}$ & $\begin{array}{l}48.5 \% \\
(n=16)\end{array}$ & $\begin{array}{l}27.1 \% \\
(n=16)\end{array}$ & $\begin{array}{c}20.7 \% \\
(\mathrm{n}=6)\end{array}$ \\
\hline $\begin{array}{c}\text { Worked } \\
\text { While in } \\
\text { H.S. }\end{array}$ & $\begin{array}{c}39.9 \% \\
(n=279)\end{array}$ & $\begin{array}{l}41.9 \% \\
(n=65)\end{array}$ & $\begin{array}{l}19.0 \% \\
(\mathrm{n}=8)\end{array}$ & $\begin{array}{l}48.7 \% \\
(n=19)\end{array}$ & $\begin{array}{l}49.2 \% \\
(n=32)\end{array}$ & $\begin{array}{l}5^{6.7 \%} \\
(\mathrm{n}=17)\end{array}$ \\
\hline $\begin{array}{c}\text { First to } \\
\text { Graduate } \\
\text { H.S. } \\
\end{array}$ & $\begin{array}{c}2.3 \% \\
(\mathrm{n}=16)\end{array}$ & $\begin{array}{l}5.8 \% \\
(\mathrm{n}=9)\end{array}$ & $\begin{array}{l}7 \cdot 3 \% \\
(n=3)\end{array}$ & $\begin{array}{l}7.7 \% \\
(\mathrm{n}=3)\end{array}$ & $\begin{array}{l}6.3 \% \\
(\mathrm{n}=4)\end{array}$ & $\begin{array}{l}3.2 \% \\
(\mathrm{n}=1)\end{array}$ \\
\hline $\begin{array}{c}\text { Attended } \\
\text { HBCU, HSI, } \\
\text { or Tribal } \\
\text { College }\end{array}$ & $\begin{array}{l}0.3 \% \\
(\mathrm{n}=2)\end{array}$ & $\begin{array}{l}32.3 \% \\
\left(\mathrm{n}=5^{\circ}\right)\end{array}$ & $\begin{array}{l}2.4 \% \\
(n=1)\end{array}$ & $\begin{array}{l}5.1 \% \\
(n=2)\end{array}$ & $\begin{array}{l}9.1 \% \\
(\mathrm{n}=6)\end{array}$ & $\begin{array}{c}\mathrm{o} \% \\
(\mathrm{n}=\mathrm{o})\end{array}$ \\
\hline $\begin{array}{l}\text { Worked for } \\
\text { Pay for } 4 \text { or } \\
5 \text { Years of } \\
\text { Undergrad }\end{array}$ & $\begin{array}{c}34.3 \% \\
(n=240)\end{array}$ & $\begin{array}{l}37 \cdot 4 \% \\
\left(\mathrm{n}=5^{8)}\right.\end{array}$ & $\begin{array}{l}28.6 \% \\
(\mathrm{n}=12)\end{array}$ & $\begin{array}{l}41.0 \% \\
(n=16)\end{array}$ & $\begin{array}{l}41.7 \% \\
(n=28)\end{array}$ & $\begin{array}{l}42.0 \% \\
(n=13)\end{array}$ \\
\hline $\begin{array}{c}\text { Received } \\
\text { Pell Grant }\end{array}$ & $\begin{array}{c}28.0 \% \\
(n=193)\end{array}$ & $\begin{array}{l}62.9 \% \\
(\mathrm{n}=95) \\
\end{array}$ & $\begin{array}{c}21.4 \% \\
(\mathrm{n}=9)\end{array}$ & $\begin{array}{l}59.0 \% \\
(n=23) \\
\end{array}$ & $\begin{array}{l}37 \cdot 3 \% \\
(\mathrm{n}=25)\end{array}$ & $\begin{array}{l}40.0 \% \\
(\mathrm{n}=12) \\
\end{array}$ \\
\hline $\begin{array}{c}\text { First to } \\
\text { Graduate } \\
\text { From } \\
\text { College } \\
\end{array}$ & $\begin{array}{c}19.0 \% \\
(n=133)\end{array}$ & $\begin{array}{l}27.7 \% \\
(\mathrm{n}=43)\end{array}$ & $\begin{array}{l}19.0 \% \\
(\mathrm{n}=8)\end{array}$ & $\begin{array}{l}43.6 \% \\
(n=17)\end{array}$ & $\begin{array}{l}25.4 \% \\
(\mathrm{n}=17)\end{array}$ & $\begin{array}{c}16.1 \% \\
(n=5)\end{array}$ \\
\hline $\begin{array}{c}\text { First to } \\
\text { Attend Law } \\
\text { School } \\
\end{array}$ & $\begin{array}{c}80.2 \% \\
(n=562)\end{array}$ & $\begin{array}{c}83.9 \% \\
(n=130)\end{array}$ & $\begin{array}{l}88.1 \% \\
(\mathrm{n}=37)\end{array}$ & $\begin{array}{l}84.6 \% \\
(n=33)\end{array}$ & $\begin{array}{l}87.9 \% \\
\left(n=5^{8)}\right.\end{array}$ & $\begin{array}{l}80.6 \% \\
(\mathrm{n}=25)\end{array}$ \\
\hline $\begin{array}{c}\text { Contributed } \\
20+\text { hrs } / \text { sem } \\
\text { of Service to } \\
\text { Underserved } \\
\text { Population }\end{array}$ & $\begin{array}{l}8.8 \% \\
(n=61)\end{array}$ & $\begin{array}{l}5^{0.3 \%} \\
(\mathrm{n}=78)\end{array}$ & $\begin{array}{l}4.8 \% \\
(n=2)\end{array}$ & $\begin{array}{l}15 \cdot 4 \% \\
(\mathrm{n}=6)\end{array}$ & $\begin{array}{l}19 \cdot 7 \% \\
(n=13)\end{array}$ & $\begin{array}{l}9 \cdot 7 \% \\
(n=3)\end{array}$ \\
\hline
\end{tabular}

Table 3 presents the descriptive statistics for each race-neutral familybackground survey items. Similar to the findings in Table 2, racial or ethnic groups were comparable on some items, yet differed on others. African-American and biracial or multiracial participants endorsed items related to growing up in a single-parent household, growing up on public assistance, and having a parent who had been incarcerated more than all other racial or ethnic groups. On the other hand, Hispanic students were 
most likely to grow up in low-income neighborhoods. White and Asian/Pacific Islander students endorsed the fewest race-neutral family background items.

Table 3. Descriptive Statistics for Survey Items Focused on Race-Neutral Family Background

\begin{tabular}{|c|c|c|c|c|c|c|}
\hline & White & Afr/Am & $\begin{array}{c}\text { Asian/ } \\
\text { PI }\end{array}$ & Hispanic & $\begin{array}{l}\text { Bi/Multi- } \\
\text { Racial }\end{array}$ & Other \\
\hline $\begin{array}{c}\text { Grew up in } \\
\text { Single-Parent } \\
\text { Household }\end{array}$ & $\begin{array}{c}15.6 \% \\
(\mathrm{n}=109)\end{array}$ & $\begin{array}{l}33 \cdot 5 \% \\
(n=52)\end{array}$ & $\begin{array}{l}21.4 \% \\
(\mathrm{n}=9)\end{array}$ & $\begin{array}{c}20.5 \% \\
(\mathrm{n}=8)\end{array}$ & $\begin{array}{l}38.5 \% \\
(n=25)\end{array}$ & $\begin{array}{r}22.6 \% \\
(\mathrm{n}=7)\end{array}$ \\
\hline $\begin{array}{l}\text { Raised by } \\
\text { Guardian }\end{array}$ & $\begin{array}{c}2.1 \% \\
(\mathrm{n}=15)\end{array}$ & $\begin{array}{l}5.8 \% \\
(\mathrm{n}=9)\end{array}$ & $\begin{array}{l}2.4 \% \\
(\mathrm{n}=1)\end{array}$ & $\begin{array}{l}2.6 \% \\
(\mathrm{n}=1)\end{array}$ & $\begin{array}{l}6.1 \% \\
(\mathrm{n}=4)\end{array}$ & $\begin{array}{l}3.2 \% \\
(\mathrm{n}=1)\end{array}$ \\
\hline $\begin{array}{l}\text { Parents Under } \\
\text { 20 When Born }\end{array}$ & $\begin{array}{c}6.1 \% \\
(n=42)\end{array}$ & $\begin{array}{l}11.0 \% \\
(\mathrm{n}=17)\end{array}$ & $\begin{array}{l}2.4 \% \\
(\mathrm{n}=1)\end{array}$ & $\begin{array}{l}13.2 \% \\
(\mathrm{n}=5)\end{array}$ & $\begin{array}{l}13.6 \% \\
(\mathrm{n}=9)\end{array}$ & $\begin{array}{l}3.2 \% \\
(\mathrm{n}=1)\end{array}$ \\
\hline $\begin{array}{c}\text { On Public } \\
\text { Assistance } \\
\text { When Growing } \\
\text { Up }\end{array}$ & $\begin{array}{c}14.6 \% \\
(n=100)\end{array}$ & $\begin{array}{l}30.3 \% \\
(n=44)\end{array}$ & $\begin{array}{l}12.5 \% \\
(\mathrm{n}=5)\end{array}$ & $\begin{array}{l}26.3 \% \\
(n=10)\end{array}$ & $\begin{array}{l}34.5 \% \\
(\mathrm{n}=20)\end{array}$ & $\begin{array}{c}13 \cdot 3 \% \\
(\mathrm{n}=4)\end{array}$ \\
\hline $\begin{array}{c}\text { Family Income } \\
\text { When in H.S. } \\
\text { was }>75 \mathrm{~K}\end{array}$ & $\begin{array}{c}60.6 \% \\
(n=418) \\
\end{array}$ & $\begin{array}{l}40.3 \% \\
(\mathrm{n}=62)\end{array}$ & $\begin{array}{l}47.6 \% \\
(\mathrm{n}=2 \mathrm{O})\end{array}$ & $\begin{array}{c}20.5 \% \\
(\mathrm{n}=8)\end{array}$ & $\begin{array}{l}5^{0.0 \%} \\
(\mathrm{n}=33)\end{array}$ & $\begin{array}{l}4^{8.4 \%} \\
(\mathrm{n}=15) \\
\end{array}$ \\
\hline $\begin{array}{c}\text { Parent has } \\
\text { been } \\
\text { Incarcerated }\end{array}$ & $\begin{array}{c}6.1 \% \\
(\mathrm{n}=42)\end{array}$ & $\begin{array}{l}15.0 \% \\
(\mathrm{n}=22)\end{array}$ & $\begin{array}{l}2.4 \% \\
(\mathrm{n}=1)\end{array}$ & $\begin{array}{l}10.8 \% \\
(n=4)\end{array}$ & $\begin{array}{c}12.7 \% \\
(\mathrm{n}=8)\end{array}$ & $\begin{array}{l}6.5 \% \\
(\mathrm{n}=2)\end{array}$ \\
\hline $\begin{array}{c}\text { Family } \\
\text { Member has } \\
\text { been } \\
\text { Incarcerated }\end{array}$ & $\begin{array}{c}14.6 \% \\
(n=100)\end{array}$ & $\begin{array}{l}27.2 \% \\
(n=40)\end{array}$ & $\begin{array}{l}7.7 \% \\
(\mathrm{n}=3)\end{array}$ & $\begin{array}{c}23 \cdot 7 \% \\
(\mathrm{n}=9)\end{array}$ & $\begin{array}{l}18.0 \% \\
(n=11)\end{array}$ & $\begin{array}{l}10.0 \% \\
(\mathrm{n}=3)\end{array}$ \\
\hline $\begin{array}{l}\text { Non-English } \\
\text { Routinely } \\
\text { Spoken when } \\
\text { Growing Up }\end{array}$ & $\begin{array}{c}6.0 \% \\
(\mathrm{n}=42)\end{array}$ & $\begin{array}{l}24.7 \% \\
(n=38)\end{array}$ & $\begin{array}{l}85 \cdot 7 \% \\
(\mathrm{n}=36)\end{array}$ & $\begin{array}{l}76.9 \% \\
(\mathrm{n}=30)\end{array}$ & $\begin{array}{l}33 \cdot 3 \% \\
(n=22)\end{array}$ & $\begin{array}{l}38.7 \% \\
(n=12)\end{array}$ \\
\hline Christian & $\begin{array}{l}82.6 \% \\
(n=579 \\
\end{array}$ & $\begin{array}{c}98.1 \% \\
(\mathrm{n}=152) \\
\end{array}$ & $\begin{array}{l}42.9 \% \\
(\mathrm{n}=18) \\
\end{array}$ & $\begin{array}{l}84.6 \% \\
(\mathrm{n}=30)\end{array}$ & $\begin{array}{l}71.2 \% \\
(\mathrm{n}=47)\end{array}$ & $\begin{array}{l}66.7 \% \\
(\mathrm{n}=20)\end{array}$ \\
\hline $\begin{array}{c}\text { Raised in } \\
\text { Predom. } \\
\text { Minority } \\
\text { Neighborhood }\end{array}$ & $\begin{array}{c}5 \cdot 5 \% \\
\left(\mathrm{n}=3^{8}\right)\end{array}$ & $\begin{array}{l}54.8 \% \\
(\mathrm{n}=8 \mathrm{o})\end{array}$ & $\begin{array}{l}15 \cdot 4 \% \\
(\mathrm{n}=6)\end{array}$ & $\begin{array}{l}48.6 \% \\
(n=18)\end{array}$ & $\begin{array}{l}26.7 \% \\
(\mathrm{n}=16)\end{array}$ & $\begin{array}{c}17.2 \% \\
(\mathrm{n}=5)\end{array}$ \\
\hline $\begin{array}{c}\text { Raised in } \\
\text { Predom. Low } \\
\text { Income } \\
\text { Neighborhood }\end{array}$ & $\begin{array}{l}12.8 \% \\
(n=85)\end{array}$ & $\begin{array}{l}32.6 \% \\
(\mathrm{n}=44)\end{array}$ & $\begin{array}{l}3.1 \% \\
(n=1)\end{array}$ & $\begin{array}{l}36.1 \% \\
(n=13)\end{array}$ & $\begin{array}{l}32.8 \% \\
(\mathrm{n}=19)\end{array}$ & $\begin{array}{c}28.6 \% \\
(\mathrm{n}=8)\end{array}$ \\
\hline
\end{tabular}

The descriptive statistics that Tables 2 and 3 present suggest a pattern where certain racial or ethnic groups were likely to endorse race-neutral items more than other racial or ethnic groups. However, it is difficult to state this definitively using descriptive analyses alone. And, although there appears to be a clear pattern in the data, it is difficult to draw meaningful inferences from 
single-item race-neutral factors. Toward this end, we conducted factor analyses to examine whether some of the single-item race-neutral factors were conceptually related.

The instrument this study used was a 29-item survey that measured demographics, race-neutral aspects of the student's identity, and attitudinal questions about diversity in law school. We conducted factor analyses (with varimax rotation) ${ }^{188}$ on both the race-neutral student-background and familybackground indices. Results from the factor analyses suggest that several items on the survey were conceptually related. Thus, it is more methodologically sound to examine these items in combined forms than as single items. Specific results from the factor analyses show four interpretable factors for the raceneutral student-background indices: (1) financial need (i.e., qualifying for free or reduced lunch in high school; working for pay in high school or receiving a Pell Grant as an undergraduate); (2) high-school characteristics (i.e., private or public); (3) family "first" status (i.e., first to graduate from a high-school or undergraduate program, first to attend law school); and (4) ethnic- or race-focused high school or college (i.e., attending a historically black college or university ("HBCU"), attending a Hispanic serving institution, contributing uncompensated services to underserved groups in college). Thus, the single-items in Table 2 fall into one of these four categories. For race-neutral family background indices, the factor analysis revealed three interpretable factors: (1) family financials (i.e., parents or guardians receiving public assistance, household income, non-English spoken in household, neighborhood predominately racial or ethnic minority or low income); (2) family incarceration (i.e., parents, guardian, or someone in the immediate family has been incarcerated); and (3) family composition (i.e., growing up in a single-parent household, being raised by a guardian, parents under the age of 20 when the student was born). The single items in Table 3 fall into these three categories, with the exception of religion, which was not conceptually related to any of the other items.

The four factors for student background indices accounted for $54.8 \%$ of the variance, and the three factors for family background indices accounted for $55.5 \%$ of the variance. We created composite variables for each interpretable factor in order to conduct further inferential analyses. Table 2 contains one example of a composite variable. There were four single-items that were conceptually related: (1) qualifying for free or reduced lunch in high school; (2) worked for pay in high school; (3) worked for pay in college; and (4) received a Pell Grant as an undergrad. We combined these four items and subsumed them under the single factor entitled "financial need." For all composite variables, higher scores indicate greater endorsement of the raceneutral indices.

Once we created the composite variables, we were able to show the mean score ratings for each racial or ethnic group on both student-background and family-background items. Table 4 presents the mean score differences

188. Varimax is an orthogonal rotation that significantly reduces the chances of multicollinearity between variables. 
between racial or ethnic groups on student-background indices. This table is similar to Table 2, with the exception that it illustrates how the single-item data from Table 2 actually tells a more complex story. These composite variables allow for a more statistically meaningful comparison between racial or ethnic groups.

Table 4. Mean Differences Between Racial or Ethnic Groups on StudentBackground Indices

\begin{tabular}{|c|c|c|c|c|c|c|}
\hline & White & Afr/Am & Asian/PI & Hispanic & $\mathrm{F}$ & Df \\
\hline $\begin{array}{c}\text { Financial } \\
\text { Needs }\end{array}$ & $\begin{array}{c}3.12 \\
(2.28)\end{array}$ & $\begin{array}{c}4.01 \\
(2.29)\end{array}$ & $\begin{array}{c}2.39 \\
(2.15)\end{array}$ & $\begin{array}{c}4.39 \\
(2.46)\end{array}$ & $10.4^{8 * * *}$ & $\begin{array}{c}3, \\
865\end{array}$ \\
\hline $\begin{array}{c}\text { H.S. } \\
\text { Characteristics }\end{array}$ & $\begin{array}{c}3.71 \\
(0.58) \\
\end{array}$ & $\begin{array}{c}3.84 \\
\left(0.4^{6}\right) \\
\end{array}$ & $\begin{array}{c}3.74 \\
(0.63)\end{array}$ & $\begin{array}{c}3 \cdot 72 \\
\left(0.5^{6}\right) \\
\end{array}$ & 2.16 & $\begin{array}{c}3, \\
927 \\
\end{array}$ \\
\hline $\begin{array}{c}\text { Family First } \\
\text { Status }\end{array}$ & $\begin{array}{c}1.02 \\
(0.66) \\
\end{array}$ & $\begin{array}{c}1.18 \\
(0.73) \\
\end{array}$ & $\begin{array}{c}1.12 \\
(0.68) \\
\end{array}$ & $\begin{array}{c}1.3^{6} \\
(0.81) \\
\end{array}$ & $5.12^{* *}$ & $\begin{array}{c}3 \\
923 \\
\end{array}$ \\
\hline $\begin{array}{l}\text { Ethnic-Focused } \\
\text { H.S. or College }\end{array}$ & $\begin{array}{c}0.19 \\
(0.41) \\
\end{array}$ & $\begin{array}{c}1.23 \\
(0.97) \\
\end{array}$ & $\begin{array}{c}0.22 \\
\left(0.4^{2}\right)\end{array}$ & $\begin{array}{c}0.74 \\
(0.71)\end{array}$ & $141.11 * * *$ & $\begin{array}{r}3, \\
868 \\
\end{array}$ \\
\hline
\end{tabular}

Note: $* p<.05, * * p<.01, * * * p .001$. Standard deviation appears in parentheses. H.S. denotes high school and Df denotes degrees of freedom.

We conducted a series of analyses of variance ("ANOVAs") to determine if the mean differences in Table 4 were significantly meaningful. As the ANOVA analyses demonstrate, there were main effects for financial needs $[\mathrm{F}(3,865)=10.48, \mathrm{p}<.001]$, family-first status $[\mathrm{F}(3,923)=5.12, \mathrm{p}<.01]$, and ethnic-or racial-focused high schools and colleges $[\mathrm{F}(3,868)=141.11, \mathrm{p}$ $<.001]$, meaning that racial or ethnic groups differed on these variables. We conducted a Bonferonni post-hoc analysis to identify where the specific difference existed. Post-hoc analyses revealed that African-American and Hispanic students scored significantly higher than both white and Asian/Pacific Islander students on financial-need indices (e.g., qualifying for free or reduced lunch in high school) and ethnic-focused high-school or college indices (e.g., attending an HBCU or Hispanic Serving Institution ("HSI")). African-American and Hispanic students also scored significantly higher than white students on family first indices.

Table 5 shows the mean score differences between racial groups on familybackground indices. ANOVA findings reveal main effects for family financials $[\mathrm{F}(3$, $8 \mathrm{oo})=32.61, \mathrm{p}<.001]$, family incarceration $[\mathrm{F}(3,895)=7.74, \mathrm{p}<.001]$, and family composition $[\mathrm{F}(3,920)=11.26, \mathrm{p}<.001]$. We again used Bonferonni post-hoc analyses to identify where differences existed. Post-hoc analyses indicate that African-American and Hispanic students scored significantly higher than white and Asian/Pacific Islander students on family-financial indices (e.g., parents or guardians received public assistance while growing up). Moreover, African-American students scored significantly higher than both white and Asian/Pacific Islander students on family-incarceration indices, and they scored significantly higher than white students on family-composition indices (e.g., growing up in a single-parent household). 
Table 5. Mean Differences Between Racial or Ethnic Groups on Family-Background Indices

\begin{tabular}{|c|c|c|c|c|c|c|}
\hline & White & Afr/Am & Asian/PI & Hispanic & $\mathrm{F}$ & Df \\
\hline $\begin{array}{c}\text { Family } \\
\text { Financials }\end{array}$ & $\begin{array}{c}2.99 \\
(2.08)\end{array}$ & $\begin{array}{c}4.81 \\
(2.77)\end{array}$ & $\begin{array}{c}3.24 \\
(1.84)\end{array}$ & $\begin{array}{c}5 \cdot 44 \\
92.91)\end{array}$ & $32.61 * * *$ & $\begin{array}{c}3, \\
800\end{array}$ \\
\hline $\begin{array}{c}\text { Family } \\
\text { Incarceration }\end{array}$ & $\begin{array}{c}0.20 \\
\left(0.5^{2}\right)\end{array}$ & $\begin{array}{c}0.43 \\
(0.71)\end{array}$ & $\begin{array}{c}0.10 \\
(0.38) \\
\end{array}$ & $\begin{array}{c}0.32 \\
(0.67) \\
\end{array}$ & $7 \cdot 74^{* * * *}$ & $\begin{array}{c}3 \\
895 \\
\end{array}$ \\
\hline $\begin{array}{c}\text { Family } \\
\text { Composition }\end{array}$ & $\begin{array}{c}0.23 \\
\left(0.5^{1}\right)\end{array}$ & $\begin{array}{l}0.5^{0} \\
(0.66)\end{array}$ & $\begin{array}{c}0.26 \\
(0.45)\end{array}$ & $\begin{array}{c}0.37 \\
(0.63)\end{array}$ & $11.26^{* * *}$ & $\begin{array}{c}3 \\
320\end{array}$ \\
\hline
\end{tabular}

Note: $* \mathrm{p}<.05, * * \mathrm{p}<.01, * * * \mathrm{p}<.001$. Standard deviation appears in parentheses. H.S. denotes high school and Df denotes degrees of freedom.

Four questions on the survey measured students' attitudes about diversity in law school. Table 6 shows the mean differences between racial or ethnic groups on these variables. We conducted a series of ANOVAs to determine if there were significant differences between racial or ethnic groups on these attitudinal indices. ANOVA findings revealed that there were main effects for students' attitudes about racial diversity improving students' educational experiences $[\mathrm{F}(3,927)=16.30, \mathrm{p}<.001]$, and for attitudes about socioeconomic diversity improving students' educational outcomes $[\mathrm{F}(3$, $927)=6.40, p<.001]$, suggesting that significant differences existed between the racial or ethnic groups. Post-hoc analyses showed that African-American and Hispanic students scored significantly higher than white students on both of these indices. However, there were no significant differences between racial or ethnic groups on attitudes about diversity of students' experiences and diversity of students' viewpoints being important. 
Table 6. Mean Differences Between Racial or Ethnic Groups on Diversity Perspectives

\begin{tabular}{|c|c|c|c|c|c|c|}
\hline & White & Afr/Am & Asian/PI & Hispanic & $\mathrm{F}$ & Df \\
\hline $\begin{array}{c}\text { Racial } \\
\text { Diversity is } \\
\text { Important }\end{array}$ & $\begin{array}{c}3.65 \\
(1.01)\end{array}$ & $\begin{array}{c}4.23 \\
(1.20)\end{array}$ & $\begin{array}{c}4.02 \\
(1.05)\end{array}$ & $\begin{array}{c}4.21 \\
(0.88)\end{array}$ & $16.30^{* * * *}$ & $\begin{array}{c}3 \\
927\end{array}$ \\
\hline $\begin{array}{c}\text { SES } \\
\text { Diversity is } \\
\text { Important }\end{array}$ & $\begin{array}{c}3.84 \\
(1.01)\end{array}$ & $\begin{array}{c}4.23 \\
(1.22)\end{array}$ & $\begin{array}{c}3.93 \\
(1.14)\end{array}$ & $\begin{array}{c}4.13 \\
(0.88)\end{array}$ & $6.40^{* * *}$ & $\begin{array}{c}3 \\
927\end{array}$ \\
\hline $\begin{array}{l}\text { Diversity of } \\
\text { Student } \\
\text { Experience } \\
\text { Important }\end{array}$ & $\begin{array}{c}4.01 \\
(0.90)\end{array}$ & $\begin{array}{c}4.04 \\
(1.07)\end{array}$ & $\begin{array}{c}4.05 \\
(0.88)\end{array}$ & $\begin{array}{c}4.05 \\
(0.71)\end{array}$ & 0.07 & $\begin{array}{c}3 \\
911\end{array}$ \\
\hline $\begin{array}{l}\text { Diversity of } \\
\text { Student } \\
\text { Viewpoint } \\
\text { Important }\end{array}$ & $\begin{array}{c}4.35 \\
(0.86)\end{array}$ & $\begin{array}{c}4.3^{6} \\
(1.17)\end{array}$ & $\begin{array}{c}4.24 \\
(1.10)\end{array}$ & $\begin{array}{c}4.53 \\
(0.61)\end{array}$ & 0.67 & $\begin{array}{c}3 \\
927\end{array}$ \\
\hline
\end{tabular}

Note: $* \mathrm{p}<.05$, **p $<.01, * * * \mathrm{p}<.001$. Standard deviation appears in parentheses. Df denotes degrees of freedom.

\section{OBSERVATIONS}

This study sought to examine the following research question: Is there a relationship between law school students' racial or ethnic backgrounds and their willingness to endorse race-neutral identity factors? Our findings suggest that, in the face of constitutional uncertainty, using race-neutral factors may enable law schools to maintain current levels of racial diversity without considering race in the admissions process. In this study, African-American and Hispanic students were significantly more likely than both white and Asian/Pacific Islander students to endorse race-neutral factors such as qualifying for free or reduced lunch programs in K-12 education, working for pay for 10 or more hours while enrolled in high school or an undergraduate program, receiving a Pell Grant during their undergraduate education, attending a high school where racial minorities comprised the majority of the student body, attending HBCUs or HSIs, and having a parent or guardian who received public assistance when they were a dependent minor. Moreover, African-American students in this study endorsed more race-neutral factors than other students, which suggests that using raceneutral factors may be particularly important for maintaining the current levels of African-American students in public law schools.

The findings of this study suggest that there is room for this type of raceblind yet race-conscious experimentation by law schools. For law schools in jurisdictions that ban higher-education institutions from considering race in their admissions, they may be able to use the identity factors identified in this study to improve their yield of non-white diverse students. For law schools in jurisdictions that permit higher-education institutions to use race in their admissions, the study provides one tool that law schools could use to test 
whether a race-neutral admission cycle could yield a critical mass of racial and ethnic minority students from groups that are underrepresented in law schools and the legal profession.

Of course, the findings reported in this study are based on aggregated data collected only from the law schools participating in it. Consequently, law schools that presently consider race in admissions, yet struggle to achieve even low levels of diversity, may suffer a loss in diversity if they stop considering race in their quest to achieve racial diversity in their classrooms and campus community. Law schools that presently enjoy significant racial diversity in their student bodies might consider experimenting with a race-blind admissions cycle by asking questions on their applications related to the interpretable identity factors presented in the findings of this study in lieu of asking about race. For law schools in jurisdictions that permit highereducation institutions to consider race in their admissions, conducting raceblind admission cycles will provide them with diversity yield rates that can be compared to previous years when they did consider race. If the race-neutral admissions cycle yielded significantly less diversity than the diversity achieved in years when they did consider race, then the law schools would have documented proof that they "considered" race-neutral alternatives before resorting to using race, and that they could not achieve comparable diversity using race-blind means. Given the Supreme Court's heightened scrutiny of universities' consideration of race in their admissions decisions, ${ }^{189}$ possessing such information may be critical to defending race conscious affirmativeaction plans against future constitutional challenges.

It is important to note that, with but a few exceptions, the overwhelming majority of the law schools that we surveyed had a paucity of racial diversity within their first-year student bodies. This, more than anything, speaks to the pressing need for law schools to continue being proactive about increasing racial diversity in their student populations. A lack of racial diversity can desensitize students to the importance of having racial diversity in the classroom. Our findings revealed ideological and attitudinal differences between racial groups on perspectives about the role of diversity in law schools, suggesting that racial diversity continues to be something that law schools must strive to achieve in order to have diverse perspectives in classrooms. Our study provides an avenue for how affirmative action in the law school context can be race-blind and therefore "race-neutral" by not asking applicants about their race, yet be race-conscious by having an admissions structure that is mindful of inclusivity and racial diversity.

\section{CONCLUSION}

Considering that law schools serve a unique role in American society and "represent the training ground for a large number of our Nation's leaders," 190 it is vital to the future of our democracy that students from historically

\footnotetext{
189. See supra Part III.B.

19o. Grutter v. Bollinger, 539 U.S. 3o6, 332 (2003).
} 
underrepresented racial groups continue to have access to legal education. As this Article discussed, the ability of law schools to continue to provide such access through the use of race-conscious admissions plans is quite uncertain. ${ }^{191}$ Coupled with the profound lack of racial diversity currently plaguing the legal profession, ${ }^{192}$ law schools' experimentation with raceneutral admissions criteria-such as those identity factors tested in our study-is both a timely and necessary endeavor. Engaging in this endeavor is crucial if we are to fulfill our commitment and duty to educate all law students in diverse learning environments and to provide students from diverse backgrounds greater access to legal education and the legal profession.

191. See supra Part III.B.

192. See supra Part II. 